\title{
MORPHOLOGICAL TRENDS OF FOUR MANILA CLAM POPULATIONS (VENERUPIS PHILIPPINARUM) ON THE FRENCH ATLANTIC COAST: IDENTIFIED SPATIAL PATTERNS AND THEIR RELATIONSHIP TO ENVIRONMENTAL VARIABILITY
}

\author{
NATHALIE CAILL-MILLY, ${ }^{1, *}$ NOËLLE BRU, ${ }^{2}$ MÉLANIE BARRANGER, ${ }^{1}$ \\ LAURENT GALLON ${ }^{3}$ AND FRANK D'AMICO ${ }^{4}$ \\ ${ }^{1}$ Ifremer, Laboratoire Ressources Halieutiques Aquitaine, FED 4155 MIRA, 1 Allée du Parc Montaury, \\ 64600 Anglet, France; ${ }^{2}$ UNIV PAU \& PAYS ADOUR, Laboratoire de Mathématiques et de Leurs \\ Applications de Pau, UMR CNRS 5142, FED 4155 MIRA, 64000 Pau, France, ${ }^{3} U N I V$ PAU \& PAYS \\ ADOUR, Laboratoire Informatique de l'Université de Pau et des Pays de l'Adour, 40004 Mont de \\ Marsan, France; ${ }^{4}$ UNIV PAU \& PAYS ADOUR, UMR ECOBIOP, FED 4155 MIRA, 1, Allée du Parc \\ Montaury, 64600 Anglet, France
}

\begin{abstract}
For species' dynamics highly influenced by environmental conditions, sustainable management for conservation and/or exploitation purposes requires the ability to segregate natural processes from anthropogenic impacts. In this context, identification of phenotypic variations in morphological patterns, and clarification of the mechanisms involved, constitute useful tools to identify adequate management measures from Europe-wide to local conditions. Although such approaches are already used effectively in the management of fish stocks, they are more recent for bivalve stocks, which are also good candidates for such management tools. The current study examines morphological patterns in the Manila clam (Venerupis philippinarum) through morphometric studies of 4 populations on the French Atlantic coast (Banc du Guer, Morbihan Gulf, Bellevue, and Arcachon Bay). The methodology relies mainly on conventional shape analysis using 8 morphometric ratios involving metrics and weight. In addition, an outline description was created for selected individuals that revealed different forms of the anterior-dorsal valve margin identified for future research. Using supervised classification methods, morphometric-latitudinal trends were revealed between northern and southern populations of $V$. philippinarum. Relationships between discriminatory morphometric ratios (describing elongation, valve density, and weight related to length) and available environmental conditions (temperature, salinity, and chlorophyll $a$ concentrations) were considered using linear multilevel models. They revealed significant relationships with chlorophyll $a$ concentrations and with 1 ratio with seawater temperature ranging from $12-20^{\circ} \mathrm{C}$. Four potential causes were hypothesized to explain the unexpected relationship identified between morphometric characteristics and trophic conditions: (1) a negative effect resulting from high chlorophyll $a$ concentrations, (2) a masked effect of other food resources affecting valve growth, (3) interspecific competition for food among filter-feeding populations, (4) and effects of other environmental parameters such as sediment type. Observed differences in shape may result from a combination of these 4 causes with varying degrees, depending on site-specific environmental conditions. Last, the consequences of morphometric variation on population regulation are addressed.
\end{abstract}

KEY WORDS: shell shape, linear morphometric methods, contour detection, environmental effect, linear multilevel model, bivalve, Atlantic Ocean, Venerupis philippinarum

\section{INTRODUCTION}

Phenotypic plasticity of bivalve shell morphometry has long been reported in the literature (Seed 1968, Yonge \& Campbell 1968, Rosenberg 1972, Brown et al. 1976, Lucas 1981, Eagar et al. 1984, Kwon et al. 1999, Costa et al. 2008). Various ecological factors are known to influence bivalve shell morphometry, including latitude (Beukema \& Meehan 1985, Fiori $\&$ Defeo 2006); depth of distribution (Claxton et al. 1998); tidal excursion or shore level (Dame 1972, Franz 1993); water movements such as waves, turbulence, and currents (Hinch \& Bailey 1988, Fuiman et al. 1999, Akester \& Martel 2000); type of sediment (Eagar et al. 1984, Claxton et al. 1998); salinity (Mariani et al. 2002); type of natural predator (Luttikhuizen et al. 2003, Nagarajana et al. 2006); and trophic conditions (Tomaru et al. 2002).

One of the most cultivated and harvested infaunal bivalves in the world, the Manila clam (Venerupis philippinarum [A. Adams and Reeve, 1850]), has been the subject of studies on the

*Corresponding author. E-mail: Nathalie.Caill.Milly@ifremer.fr DOI: $10.2983 / 035.033 .0205$ relationship between morphometry and environmental factors. These studies have highlighted the impacts of trophic conditions (Watanabe \& Katayama 2010), currents (Kakino 1996), and offshore/inshore localization (Nakamura et al. 2002) on morphometry. Effects of clam density on morphology have also been reported by Ohba (1956), Bourne and Adkins (1985), and Cigarría and Fernandez (1998). Most of these studies rely on conventional shape analysis methods that use distances, ratios, and angles between basic landmarks on the bivalve shell. In contrast, very few works have used outline shape analysis, such as Fourier series representations (Costa et al. 2008). The majority of these studies have concerned Japanese populations of $V$. philippinarum. Surprisingly few studies of this type have dealt with European stocks (Costa et al. 2008), despite the utility of identifying similarities and differences in responses for inferring mechanisms involved in generating morphological variation. Such analyses could contribute to conservation of the species by segregating natural processes from anthropogenic impacts to develop specific management measures for local conditions. From local to broader management scales, it could, for instance, impact the definition of appropriate protected areas or regulations based 
on individual size, which currently refer only to a minimum catchable shell length. The importance of morphological studies to fish stock management is well known (Cadrin 2000, Cadrin \& Friedland 2005); such approaches have only recently been applied to bivalves (Márqueza et al. 2010).

In this context, the current study focuses on whether spatial patterns exist in the morphological characteristics of 4 Venerupis philippinarum populations along the French Atlantic coast and whether any of the observed morphological patterns could be related to selected environmental parameters. The study primarily uses conventional methods that are complemented by an outline approach.

\section{MATERIALS AND METHODS}

\section{Study Sites}

Four intertidal sites along the French Atlantic coast were selected for a comparative morphometric study of interpopulation variation in the shell morphometrics of Venerupis philippinarum: Banc du Guer, Morbihan Gulf, Bellevue, and Arcachon
Bay (Fig. 1). Various criteria were used to select sites, including both the presence of important Manila clam populations along a latitudinal gradient and the availability of standardized environmental data for each site.

The natural oyster deposit located at the mouth of the Léguer River in North Brittany is called Banc du Guer. The estuary is approximately $2.7 \mathrm{~km}^{2}$ and has one channel. A large sandy structure is located to the northwest of the bay (Augris \& Simplet 2011). At its mouth, the bottom is composed mainly of fine-shell sand. A facies characterized by a heterogeneous mixture of branches and debris of calcareous algae also occurs in this zone. The proportion of gravels tends to increase toward the middle of the bay (Augris \& Simplet 2011). Manila clams were located primarily in substratum composed of sand or mud and gravel. This bay is strongly influenced by tide levels. Currents are stronger in the outer bay than the inner one. Tidal current velocities range from 1.5-2 knots (Anonymous 1975). Salinity varies little during the year in the downstream part of the estuary (Anonymous 2012a).

The Morbihan Gulf is a macrotidal-dominated system. It has a surface area of $115 \mathrm{~km}^{2}$ and an average depth of $4.4 \mathrm{~m}$. It is

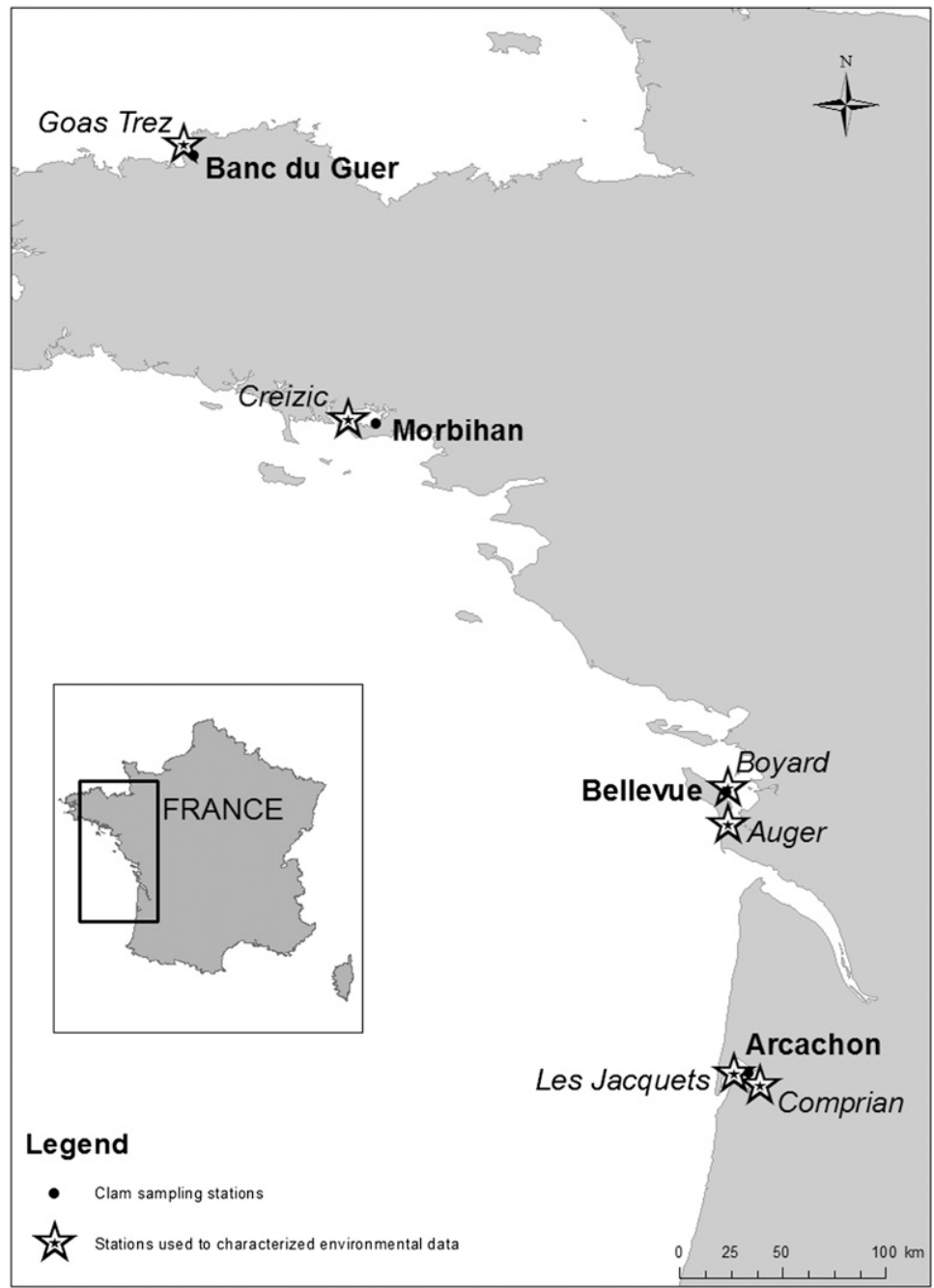

Figure 1. Maps showing the 4 sampling sites and the stations used to characterize environmental data. Sources: ESRI, Lissardy (pers. comm., June 2012). 
dotted with islands and islets, and opens to the ocean through a 0.9-km-wide bottleneck (Azandegde 2010), making it well sheltered. This narrow seaward opening combined with deep valleys (corresponding to old, flooded rivers) results in complex hydrodynamics, with high-speed currents in its western portion and reduced currents in its eastern portion (Anonymous 2006). Hydrosedimentary processes are controlled largely by the orientation of the islands, although rapid changes have been observed. The eastern basin has finer sediments that settle on the substratum as silt. Bernard and Chauvaud (2002) described the sediments of this area as sandy mud and fine sand that is more or less silted. Manila clams are exploited in the eastern basin; Zostera noltei seagrass meadows are also listed.

Bellevue is located in the western part of Marennes-Oleron Bay, which is a semiclosed bay connected to the Bay of Biscay by the Pertuis d'Antioche in the north and the Pertuis de Maumusson in the south. This area is fairly shallow, with the presence of islands leading to a complex hydrology (Anonymous 2012b). Toward the coast, sedimentation is encouraged by the break of the swell. Transit currents move from north to south (through the 2 Pertuis). Hydrodynamics are dominated locally by swell action and tidal currents generating strong superficial changes in intertidal sand distribution (Le Hir et al. 2010). Although limited, these intertidal sand areas host a large proportion of the Manila clam population.

Arcachon Bay is a $156-\mathrm{km}^{2}$ semisheltered lagoon composed mostly of intertidal flats $\left(110 \mathrm{~km}^{2}\right.$ within the inner lagoon). This mesotidal system is characterized by a sediment composition ranging from mud to muddy sands and is colonized by vast Zostera noltei seagrass meadows. Influenced by both external neritic waters and by continental inputs (Dang 2009), the bay has a semidiurnal macrotidal rhythm. Temperature and salinity gradients within the bay are controlled by the characteristics of these water masses as well as by slow tidal water renewal (Plus et al. 2006). The Manila clam population is located primarily on the east and the northwest sides of the bay.

\section{Sampling Collection}

The shells of Venerupis philippinarum were collected between March 2010 and March 2012 (Table 1). For the Arcachon and Morbihan sites, a Hamon grab was used at high tides, and sediment cores were filtered onboard. For Banc du Guer and Bellevue, the samples were taken at low tide by hand within quadrats. For both techniques, samples consisted of sediment cores of $0.25 \mathrm{~m}^{2}(0.5 \times 0.5 \mathrm{~m})$, taken to a depth greater than the maximum buried depth for Manila clams (10-12 cm when the temperature is very low [Le Treut 1986]). Sampling stations were defined randomly for each site and identified by their geographic coordinates. For each sample, after the clams were sorted, they were placed immediately in a plastic bag in an icebox onboard. At the end of the trip (within $5 \mathrm{~h}$ of sample collection), the clams were brought back to the laboratory and stored at $-20^{\circ} \mathrm{C}$ until they were analyzed. To limit potential size dependency (Fan et al. 2007) on measured morphometric characteristics, only individuals between $35.0 \mathrm{~mm}$ and $37.5 \mathrm{~mm}$ in shell length were subsampled for each site. The level and the variability of shell length among sites were similar (KruskalWallis test: chi-square $=5.394, d f=3, P=0.1451$; Levene test: $\mathrm{F}=0.3296, d f=3, P=0.804)$.

\section{Environmental Conditions}

Data from the national database Quadrige ${ }^{2}$ (Belin et al. 2013) were used to assess the hydrological conditions prevailing at each site and their potential influence on Manila clam morphometric characteristics. The main objectives of this database are to manage and exploit data provided by environmental survey networks undertaken by Ifremer. Sampling is conducted once a week or twice a month (depending on the parameters), alternatively at slack-water low tide (by high coefficient) and high tide (by low coefficient). For this study, we used both the Phytoplankton and Phycotoxins Monitoring Network and the Hydrological Monitoring Network for Arcachon Bay (Belin et al. 2013). Parameters describing seawater temperature, salinity, and chlorophyll $a$ concentration (considered to be an indicator of trophic resources, according to Shibata et al. 1999) were selected to test potential influence of environmental conditions on bivalve shell morphometry.

To limit interannual variability of the environmental parameters for each site, we decided to use data for these parameters collected for the 3 y preceding clam sampling. This 3 -y period also roughly corresponded to the age of the studied clams (deduced from Le Treut [1986]). Six stations for environmental data collection (i.e., Goas Trez, Creizic, Boyard, Auger, Les Jacquets, and Comprian) were considered representative because of their proximity to the 4 study sites (Fig. 1). For study sites with 2 nearby stations (i.e., Bellevue and Arcachon), data were pooled.

From these data, 2 types of complementary metrics were defined. On the one hand, classic metrics (mean, median, and SD) were calculated. On the other hand, specific temporal aggregations were also considered for temperature to focus on its potential effects because numerous authors agree that the

TABLE 1.

Sample locations of Venerupis philippinarum characterized by their geographic coordinates, sampling periods, number of subsampled individuals between 35.0 and $37.5 \mathrm{~mm}$ in shell length, and average shell length and weight $( \pm S D)$ of the subsampled clams.

\begin{tabular}{lcccc}
\hline \hline & Banc du Guer & Morbihan Gulf & Bellevue & Arcachon Bay \\
\hline Geographic coordinates & $48^{\circ} 44^{\prime} \mathrm{N}$ & $47^{\circ} 33^{\prime} \mathrm{N}$ & $45^{\circ} 56^{\prime} \mathrm{N}$ & $44^{\circ} 43^{\prime} \mathrm{N}$ \\
Sampling date & $03^{\circ} 32^{\prime} \mathrm{W}$ & $02^{\circ} 44^{\prime} \mathrm{W}$ & $01^{\circ} 13^{\prime} \mathrm{W}$ & $01^{\circ} 07^{\prime} \mathrm{W}$ \\
No. of subsampled clams between $35.0 \mathrm{~mm}$ and $37.5 \mathrm{~mm}$ & Mugust 2011 & March 2010 & March 2012 & May June 2010 \\
Mean length of subsampled clams $(35.0-37.5 \mathrm{~mm})$ & 31 & 43 & 79 & 85 \\
Mean weight of subsampled clams $(35.0-37.5 \mathrm{~mm})$ & $36.4 \pm 0.7 \mathrm{~mm}$ & $36.2 \pm 0.7 \mathrm{~mm}$ & $36.4 \pm 0.8 \mathrm{~mm}$ & $36.2 \pm 0.8 \mathrm{~mm}$ \\
\hline
\end{tabular}


temperature effect acts mainly on the growth function in Venerupis species (Laing et al. 1987, Toba 1987 in Nakamura et al. 2002, Beiras et al. 1994, Fan et al. 2007). Manila clams in the Thau lagoon did not grow at temperatures less than $6^{\circ} \mathrm{C}$, with optimal maintenance occurring between $12^{\circ} \mathrm{C}$ and $20^{\circ} \mathrm{C}$ (Maitre-Allain 1982). In Jiaozhou Bay, China, the most suitable temperature range for Manila clam shell growth was estimated to be between $18^{\circ} \mathrm{C}$ and $23^{\circ} \mathrm{C}$ (Fan et al. 2007). In our work, we used the growth pattern established for the Thau lagoon (Maître-Allain 1982) to calculate (per site) 2 complementary characteristics: the percentage of observed water temperatures less than $6^{\circ} \mathrm{C}$ and the percentage of those observed between $12^{\circ} \mathrm{C}$ and $20^{\circ} \mathrm{C}$ (Table 2).

\section{Shell Preparation and Classic Morphology Descriptors}

In the laboratory, all the shells were cleaned, dried at $38^{\circ} \mathrm{C}$ for $48 \mathrm{~h}$, and the valves were separated. Then, for each clam, 2 high-resolution pictures (lateral and ventral views) of the left valve were taken using TNPC software (Digital Processing for Calcified Structures, www.TNPC.fr) and image analyses were performed. Six physical parameters were retained and used to express ratios. These parameters consisted of linear and surface measures obtained directly from the shape analysis (lateral and ventral views) and a weight measure of each left valve. Respective accuracies of $1 \times 10^{-4} \mathrm{~mm}$ and $0.1 \mathrm{mg}$ are associated with the linear and weight measures:

- Length $(L)$, defined as the longest distance from the front edge to the back edge (in millimeters). It is the reference length obtained from the lateral view

- Height $(H)$, defined as distance from the umbo to edge (in millimeters) obtained from the lateral view

- Width $(W)$, defined as longest distance of the valve in the lateral plane across the valve (in millimeters) obtained from the ventral view

- Lateral area $(A l)$, defined as the surface of the valve projected on a plane in the lateral view

- Ventral area $(A v)$, defined as the surface of the valve projected on a plane in the ventral view

- Weight or shell mass $(S M)$, defined as the dry mass of the left valve (in milligrams)

Eight classic morphometric variables were used to describe and compare the morphology of individuals at the different sites, including 3 sharpness indices defined as the elongation index $\left(\frac{H}{L}\right)$, compactness index $\left(\frac{W}{L}\right)$, and the convexity index $\left(\frac{W}{H}\right) ; 3$ weight linear ratios $\left(\frac{S M}{L}, \frac{S M}{H}\right.$, and $\left.\frac{S M}{W}\right)$; and 2 weight surface ratios $\left(\frac{S M}{A l}\right.$ and $\left.\frac{S M}{A v}\right)$ (see Table 3 for details).

\section{Representation of Clam Shapes Using Contour Detection}

In addition to classic morphometric descriptors, a first representation of clam shapes (in the lateral view) was determined using the contour detection technique. For each site, a typical valve representing morphometric ratios close to the average ratios of the site was selected. Outlines of these valves were obtained from images using an active contour, or snake, method (Kass et al. 1988) followed by using a Canny filter (Canny 1986) to extract frontier boundaries. This contour-based approach allowed visualization of the medium profile to compare shape differences. The initial use of this method did not take into account individual variability comparing classic morphometric analyses.

\section{Statistical Analysis}

Statistical analysis of the data included (1) a description of the biometric variables $\left(\frac{H}{L}, \frac{W}{L}, \frac{W}{H}, \frac{S M}{L}, \frac{S M}{H}, \frac{S M}{W}, \frac{S M}{A l}, \frac{S M}{A v}\right)$ related to the sites and individual classification and (2) a multilevel modeling to highlight the relationships between biometry and environmental parameters. To address those relationships, the 8 biometric variables were considered in relation to 8 metrics describing environmental conditions, some indicating level values and others variability (i.e., median temperature, SD of temperature, temperature values $<6^{\circ} \mathrm{C}$, temperature values between $12^{\circ} \mathrm{C}$ and $20^{\circ} \mathrm{C}$, median salinity, SD of salinity, median chlorophyll $a$ concentration, SD of chlorophyll $a$ concentration).

\section{Description of the Biometric Variables Related to the Sites and Individual Classification}

Shell length and variability were similar among sites. Significant differences among the morphometric ratios were tested with Kruskal-Wallis tests using a type I error rate of 0.05 . Morphometric features for each site were then examined from a multivariate point of view, using descriptive multivariate

TABLE 2.

Seawater temperature, salinity, and chlorophyll $a$ concentration at the 4 sites.

\begin{tabular}{|c|c|c|c|c|}
\hline & Banc du Guer & Morbihan Gulf & Bellevue & Arcachon Bay \\
\hline Mean temperature $\left({ }^{\circ} \mathrm{C}\right)$ & 13.6 & 13.8 & 14.2 & 15.2 \\
\hline Median temperature $\left({ }^{\circ} \mathrm{C}\right)$ & 14.0 & 15.0 & 14.9 & 15.5 \\
\hline Temperature SD $\left({ }^{\circ} \mathrm{C}\right)$ & 3.8 & 4.3 & 4.5 & 5.6 \\
\hline$\%$ of temperature values $<6^{\circ} \mathrm{C}(\%)$ & $<0.1$ & 2.7 & 2.3 & 3.5 \\
\hline$\%$ of temperature values between $12^{\circ} \mathrm{C}$ and $20^{\circ} \mathrm{C}$ & 60.5 & 65.3 & 51.2 & 38.7 \\
\hline Mean salinity & 34.2 & 33.2 & 33.5 & 30.6 \\
\hline Median salinity & 34.6 & 34.0 & 33.6 & 31.1 \\
\hline Salinity SD & 1.3 & 1.8 & 1.4 & 2.3 \\
\hline Mean chlorophyll $a(\mu \mathrm{g} / \mathrm{L})$ & 1.3 & 1.8 & 3.0 & 3.1 \\
\hline Median chlorophyll $a(\mu \mathrm{g} / \mathrm{L})$ & 1.1 & 1.4 & 2.4 & 2.5 \\
\hline Chlorophyll $a \mathrm{SD}(\mu \mathrm{g} / \mathrm{L})$ & 0.9 & 1.6 & 2.0 & 2.3 \\
\hline
\end{tabular}


TABLE 3.

Computations, ranges, and interpretations of the morphometric variables used to describe morphological characteristic among sites.

\begin{tabular}{|c|c|c|c|}
\hline Indicators & Computations (units) & Minimum-maximum (SD) & Interpretations \\
\hline Elongation index & $\frac{H}{L}$ (dimensionless) & $0.65-0.82(0.03)$ & $\begin{array}{l}\text { The slender character of the valve from a lateral } \\
\text { view. The smaller the ratio, the more slender } \\
\text { the valve from a lateral view. }\end{array}$ \\
\hline Compactness index & $\frac{W}{L}$ (dimensionless) & $0.24-0.40(0.02)$ & $\begin{array}{l}\text { The compactness of the valve from a ventral } \\
\text { view. The greater the ratio, the more dome }\end{array}$ \\
\hline Convexity index & $\frac{W}{H}$ (dimensionless) & $0.33-0.50(0.03)$ & $\begin{array}{l}\text { A curved character of the valve, but from a } \\
\text { frontal view. The greater the ratio, the more } \\
\text { convex the valve from a frontal view. }\end{array}$ \\
\hline Weight linear ratio 1 & $\frac{S M}{L}(\mathrm{~g} / \mathrm{cm})$ & $0.35-1.57(0.19)$ & $\begin{array}{l}\text { The valve weight related to length. The greater } \\
\text { the ratio, the heavier the valve with respect } \\
\text { to its length. }\end{array}$ \\
\hline Weight linear ratio 2 & $\frac{S M}{H}(\mathrm{~g} / \mathrm{cm})$ & $0.47-2.04(0.23)$ & $\begin{array}{l}\text { The valve weight related to the height. The } \\
\text { greater the ratio, the heavier the valve } \\
\text { with respect to its height. }\end{array}$ \\
\hline Weight linear ratio 3 & $\frac{S M}{W}(\mathrm{~g} / \mathrm{cm})$ & $1.14-4.78(0.52)$ & $\begin{array}{l}\text { The valve weight related to the width. The } \\
\text { greater the ratio, the heavier the valve with } \\
\text { respect to its width. }\end{array}$ \\
\hline Weight surface ratio 1 & $\frac{S M}{A l}\left(\mathrm{~g} / \mathrm{cm}^{2}\right)$ & $0.17-0.73(0.08)$ & $\begin{array}{l}\text { The density of the valve (expressed in grams } \\
\text { per square centimeters); concerns the surface } \\
\text { of the valve projected on a plane in a lateral } \\
\text { view. Bear in mind that the thickness of the } \\
\text { valve is not taken into account. The greater } \\
\text { the ratio, the denser the valve for this } \\
\text { surface area. }\end{array}$ \\
\hline Weight surface ratio 2 & $\frac{S M}{A v}\left(\mathrm{~g} / \mathrm{cm}^{2}\right)$ & $0.48-1.95(0.20)$ & $\begin{array}{l}\text { The density of the valve (expressed in grams } \\
\text { per square centimeters); concerns the surface of } \\
\text { the valve projected on a plane in a ventral } \\
\text { view. Bear in mind that the thickness of the } \\
\text { valve is not taken into account. The greater } \\
\text { the ratio, the denser the valve for this } \\
\text { surface area. }\end{array}$ \\
\hline
\end{tabular}

statistical analysis. Normality of each morphometric ratio was not observed at any site in the original data. For a given parameter, the processing needed to achieve normality differed among sites. Moreover, equality of the variance-covariance matrix at each site was not satisfied. Under these conditions, usual classification methods such as linear discriminant analysis, quadratic discriminant analysis, or heteroscedastic linear discriminant analysis were not well adapted to our data to confirm the observed variations among the sites. We chose to implement the classification tree, which is a data-mining method used to implement supervised classification. The aim of this analysis is to find rules built from a set of explanatory variables that can separate the values of the target variable-in the sense that it has the advantage of not requiring any binding assumption on the variables distributions, except that the target variable, if qualitative, should not contain rare outcomes. The obtained rules, which take into account interactions between the variables, can be displayed graphically using a binary tree. The hierarchical power of separability of each explanatory variable on the target variable can be interpreted. Statistical evaluation of the quality of the results is possible through several error rates of misclassification.

After a classification tree is constructed, it is essential to validate its use by estimating the probability that the predicted class for any data is correct. This appraisal depends on the data set used to compute it. So, this is a random variable. The methodology used to manipulate such a tool consists of constructing a sequence of nested subtrees with an increasing number of parameters. We then selected 1 of these trees using a 10 -fold cross-validation estimate of the misclassification rate, which is an estimate of the probability of misclassifying a new datum. This step, called pruning, led to selecting a tree that had the best predictive power while being parsimonious. It provided a simplification of the classification tree and made it easier to comprehend while avoiding overfitting.

The proportion of statistical units with a class that is poorly predicted by the tree calculated on the whole sample is called the resubstitution error rate. The confusion matrix summarizes the reclassification of the observations and allows identification of which outcome of the target variable is poorly predicted by the selected tree.

\section{Multilevel Modeling to Highlight the Relationships Between Biometry} and Environmental Parameters

The morphometric ratios identified as the most discriminatory by the previous classification method were considered separately as dependent variables of the variability of environmental conditions. For each of these variables, a linear multilevel 
model (LMM; also called a mixed-effects linear model) was fitted using site and the associated environmental conditions to quantify the dependencies. To do this, we followed the sequence of steps proposed by Bliese (2012):

- Step 1: A "null" mixed model is created, taking into account only sites by examining intercept variability among sites (random effect). The intraclass correlation coefficient is then calculated to determine the proportion of total variance attributable to between-site variance. We compared this null model and the model without a random intercept by assessing model contrasts using an analysis of variance function.

- Step 2: Environmental conditions were then added, one by one, as predictors (fixed effect) to build several multilevel models. Because these models are nested, we used a likelihood ratio test to evaluate the significance of adding each environmental condition and a combination of several environmental conditions to the null model. The final LMMs retained were as parsimonious as possible. To evaluate the gain of adding predictors on within- and between-site variances, we calculated the percentages of variance explained with the following formula:

Variance explained $=1-\left(\frac{\text { Variance with predictors }}{\text { Variance without predictors }}\right) \times 100$

Goodness of fit was then analyzed using associated residuals and a normal Q-Q plot.

Calculations were carried out with R Software (R Core Team 2013). The following packages were used: FactoMineR for simple descriptive statistics (Husson et al. 2013) and rpart for classification trees (Therneau et al. 2013). Linear multilevel models were performed using the lmer procedure from the lme4 library (Bates et al. 2013) and the nlme library (Pinheiro et al. 2014).

\section{RESULTS}

\section{Spatial Heterogeneity of Morphometric Characteristics}

For the 238 samples, the mean values of elongation $\left(\frac{H}{L}\right)$, compactness $\left(\frac{W}{L}\right)$, and convexity $\left(\frac{W}{H}\right)$ indices were $0.74 \pm 0.03$ (SD), $0.29 \pm 0.02$, and $0.40 \pm 0.03$, respectively (Table 4). By comparison with traditional forms (circular or elliptical), valve shape is better described as circular when it is seen from the lateral view and elliptical when seen from the ventral view. The mean weight ratios ranged from $0.97 \pm 0.19$ for $\left(\frac{S M}{L}\right)$ to $3.29 \pm$ $0.52 \mathrm{~g} / \mathrm{cm}$ for $\left(\frac{S M}{W}\right)$, and depended on the linear measure concerned (Table 4). The mean weight-to-surface ratios were $0.47 \pm 0.47 \mathrm{~g} / \mathrm{cm}^{2}$ in the lateral view $\left(\frac{S M}{A l}\right)$ and $1.34 \pm 0.20 \mathrm{~g} /$ $\mathrm{cm}^{2}$ in the ventral view $\left(\frac{S M}{A v}\right)$. Individual variation around the mean values was much smaller for the 3 sharpness indices than for the other ratios (Table 4).

Distributions of these morphometric parameters appeared to vary among sites along a north/south gradient (Fig. 2, Appendix). In particular, the valves from Banc du Guer had a lower mean $\frac{H}{L}$ ratios, suggesting they were more ovoid than the valves from the Arcachon Bay and Bellevue, which had greater mean $\frac{H}{L}$ values and appeared rounder from the lateral view (Fig. 2). In terms of compactness, individuals from Bellevue displayed overall greater mean $\frac{W}{L}$ ratios. For ratios regarding weight and linear or surface variables, differences between northern sites (Banc du Guer and Morbihan Gulf) and southern sites (Bellevue and Arcachon Bay) were observed such that shell valves from the southern sites tended to have

TABLE 4.

Morphometric characteristics of global sample $(n=238)$.

\begin{tabular}{|c|c|c|c|c|c|c|c|c|c|}
\hline \multirow[b]{2}{*}{ Indicators } & \multirow[b]{2}{*}{ Minimum } & \multirow[b]{2}{*}{$25 \%$} & \multirow[b]{2}{*}{$50 \%$} & \multirow[b]{2}{*}{ Mean } & \multirow[b]{2}{*}{ SD } & \multirow[b]{2}{*}{$75 \%$} & \multirow[b]{2}{*}{ Maximum } & \multicolumn{2}{|c|}{$\begin{array}{l}\text { Kruskal-Wallis statistics } \\
\text { to test spatial differences } \\
\quad(\text { factor }=\text { station })\end{array}$} \\
\hline & & & & & & & & Chi-square value & $P$ value \\
\hline $\bar{H}$ & 0.65 & 0.72 & 0.74 & 0.74 & 0.03 & 0.76 & 0.82 & 105.89 & $2.2 \mathrm{e}^{-16}$ \\
\hline$\frac{W}{L}$ & 0.24 & 0.28 & 0.29 & 0.29 & 0.02 & 0.31 & 0.40 & 44.82 & $1.012 \mathrm{e}^{-09}$ \\
\hline$\frac{W}{H}$ & 0.33 & 0.38 & 0.40 & 0.40 & 0.03 & 0.41 & 0.50 & 30.59 & $1.039 \mathrm{e}^{-06}$ \\
\hline$\frac{S M}{L}$ & 0.35 & 0.83 & 0.95 & 0.97 & 0.19 & 1.10 & 1.57 & 59.43 & $7.797 \mathrm{e}^{-13}$ \\
\hline$\frac{S M}{H}$ & 0.47 & 1.15 & 1.30 & 1.31 & 0.23 & 1.46 & 2.04 & 38.53 & $2.18 \mathrm{e}^{-08}$ \\
\hline$\frac{S M}{W}$ & 1.14 & 2.97 & 3.28 & 3.29 & 0.52 & 3.62 & 4.78 & 52.75 & $2.076 \mathrm{e}^{-11}$ \\
\hline$\frac{S M}{A l}$ & 0.17 & 0.41 & 0.46 & 0.47 & 0.08 & 0.52 & 0.73 & 39.87 & $1.133 \mathrm{e}^{-08}$ \\
\hline$\frac{S M}{A v}$ & 0.48 & 1.20 & 1.32 & 1.34 & 0.20 & 1.46 & 1.95 & 64.24 & $7.31 \mathrm{e}^{-14}$ \\
\hline
\end{tabular}




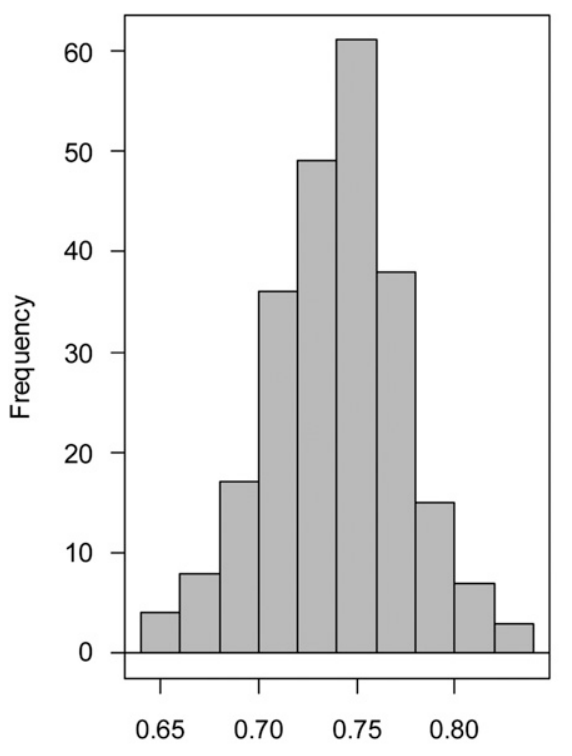

$\mathrm{H} / \mathrm{L}$

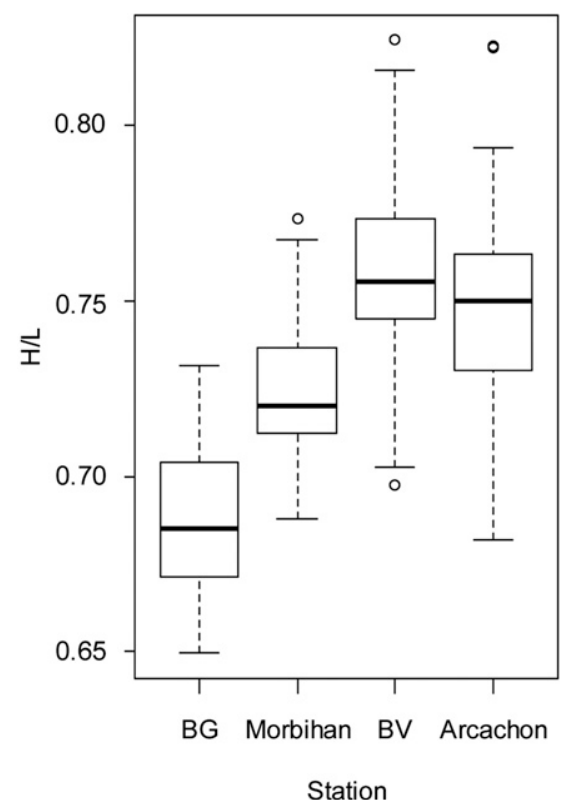

Station

Figure 2. $\frac{H}{L}$ frequency distribution for the entire data set and box plot according to factor site.

greater ratios than those from northern sites. Valves from Arcachon Bay displayed a high variability in these ratios (Appendix).

Kruskal-Wallis tests applied to each ratio $(d f=3, P<$ $1.039 \mathrm{e}^{-06}$ ) confirmed significant differences among sites (Table 4); $\frac{H}{L}, \frac{S M}{A v}$, and $\frac{S M}{L}$ had the greatest chi-square values.

Representation of active contours detected on the 4 valves considered as typical of each of them at the 4 sites (Fig. 3) completed the description of the shell. It illustrates the flattened character (for the lateral view) of the shell from Banc $\mathrm{du}$ Guer particularly in contrast to Bellevue and Arcachon Bay shells. These illustrations reveal distinct differences in the anterior-dorsal regions of the 4 valves, a characteristic that cannot be detected using conventional descriptors. The shells from the Arcachon and Bellevue sites exhibited a more curved shape than those from the other 2 sites.

The selected classification tree is displayed in Figure 4. It confirmed the discriminating power of the ratios $\frac{H}{L}, \frac{S M}{A v}$, and $\frac{S M}{L}$, because their combination led to the greatest predictive accuracy. They illustrated a more or less round shape from the lateral view and accounted for density in linear or surface measures to distinguish the 4 sites. Valves from Banc du Guer and Morbihan were discriminated by only 1 characteristic: the $\frac{H}{L}$ ratio. This ratio was less than 0.69 for Banc du Guer and ranged from 0.69-0.73 for Morbihan. Arcachon shell valves were characterized by high values of $\frac{H}{L}(>0.73)$ and $\left(\frac{S M}{A v}\right)(>1.4)$, and

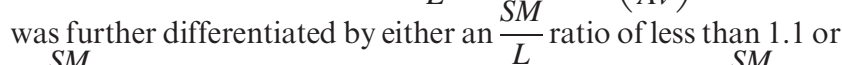
an $\frac{S M}{L}$ ratio of more than 1.1 , but was associated with an $\frac{S M}{A v}$ ratio of more than 1.6. Shell valves from Bellevue were also marked by a high $\frac{H}{L}$ ratio $(>0.73)$ but were then differentiated from
Arcachon shells by 2 modalities as individuals, with an $\frac{S M}{A v}$

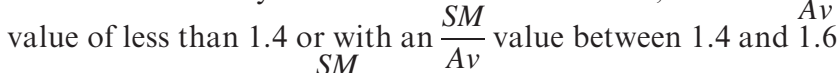
associated with a high $\frac{S M}{L}(>1.1 ;$ Fig. 4$)$.

The misclassification rate was $47 \%$, indicating that the estimated probability of a new observation being classified incorrectly was $47 \%$. The resubstitution rate was $38 \%$, indicating that $38 \%$ of the observations in our data set were misclassified.

The confusion matrix is presented in Table 5. The proportions of individuals classified correctly into their original group were greater for Bellevue and Morbihan, at $81 \%$ and $72 \%$, respectively. Banc du Guer and Arcachon displayed lower percentages of $55 \%$ and $41 \%$, respectively.

\section{Relationship Between Environmental Conditions and Morphometry}

For the three considered morphometric ratios $\left(\frac{H}{L}, \frac{S M}{A v}\right.$, and $\left.\frac{S M}{L}\right)$, the percentage of variation in individuals' morphometric values as a function of site was estimated to vary from $27 \%-61 \%$ (Table 6). The $\frac{H}{L}$ ratio had the greatest interclass correlation coefficient.

When predictors were taken into account, the LMM indicated that the 3 ratios were significantly related to environmental parameters (Table 6). The percentages of between-site intercept variance explained by these predictors were high, ranging from $71 \%-88 \%$, depending on ratios. The latter shared a common feature: relationships with trophic condition expressed by the median of chlorophyll $a$. The ratio $\frac{S M}{A v}$ displayed additional significant correlations with temperature descriptors (temperature values between $12^{\circ} \mathrm{C}$ and $20^{\circ} \mathrm{C}$ ) and with the SD of chlorophyll $a$. This last indicator also influenced $\frac{H}{L}$ ratios. For $\frac{H}{L}$ 

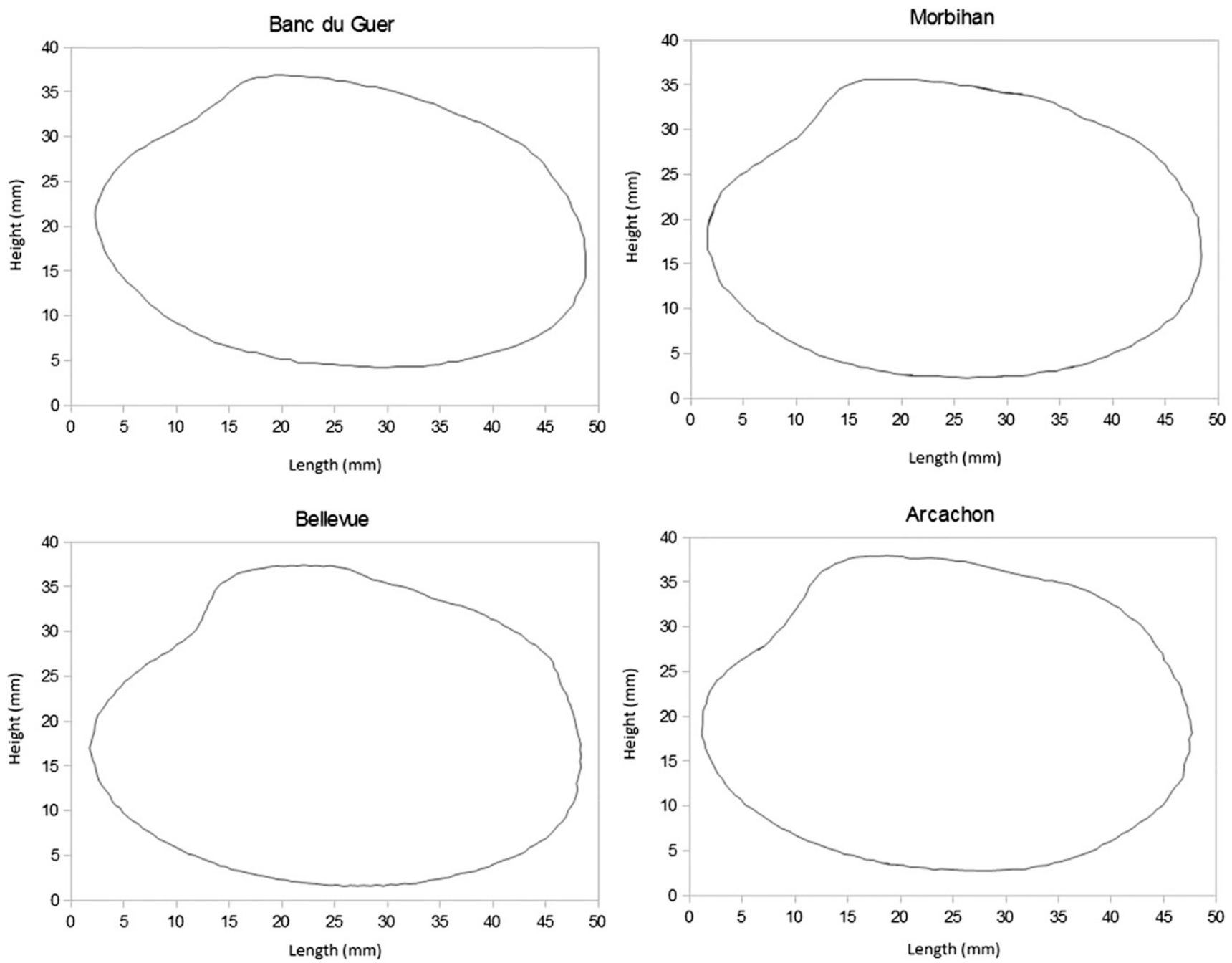

Figure 3. Representation of active contours ("snakes technique") detected on 4 valves considered typical of each of the 4 site valves. (A) Banc du Guer. (B) Morbihan Gulf. (C) Bellevue. (D) Arcachon Bay.

ratios, residuals displayed a well-aligned distribution whereas for the $\frac{S M}{A v}$ and $\frac{S M}{L}$ ratios, incorrectly adjusted points occurred at the distribution extremities (Fig. 5).

\section{DISCUSSION}

\section{Emphasis of North-South Differences in Morphometric Patterns}

For the 4 study sites, the elongation index appeared to be a discriminating criterion, with substantially lower values for Banc du Guer than for Arcachon and Bellevue. The more ovoid nature of shells from north Brittany (and, to a lesser extent, in Morbihan) was similar to observations made on Manila clams of similar shell length from the northwest of France (Normandy), in Tunisia, and in Italy (respectively by Gérard [1978], Geri et al. [1996], and Ben Ouada et al. [1998]). In Arcachon Bay, the rounder shell shape observed from the lateral view had been described previously by Caill-Milly et al. (2012). Our results indicated shells from Bellevue were similarly shaped. Concerning compactness, the average $\frac{W}{L}$ ratio for the 4 sites was
$0.29 \pm 0.02$. Although this characteristic did not vary significantly among these sites, this value was high compared with other data available in the literature (Gérard 1978, Geri et al. 1996, Ben Ouada et al. 1998). Very few comparisons with other Manila clam populations could be made for the other morphometric ratios used in this study because of their limited use in the available literature.

Within the 4 studied populations, 2 morphotypes were recognized: a northern pattern characterized by more ovoid valves of relatively low weight based on linear or surface measures and a southern pattern featuring opposite characteristics. Berke et al. (2013) found no size-latitude trends (calculated as the geometric mean of shell length and height on a $\log _{2}$ scale) for venerid clams, whereas the current study indicated the presence of a latitude influence on Manila clam shell morphometrics. On a finer scale, discrimination using classic morphometric variables among the 4 populations was less obvious. High polymorphism has been demonstrated by Ben Ouada et al. (1998) both between populations and within populations in Venerupis decussatus. Genetic reasons were also proposed to explain such variations by Moraga (1984) and Jarne et al. 


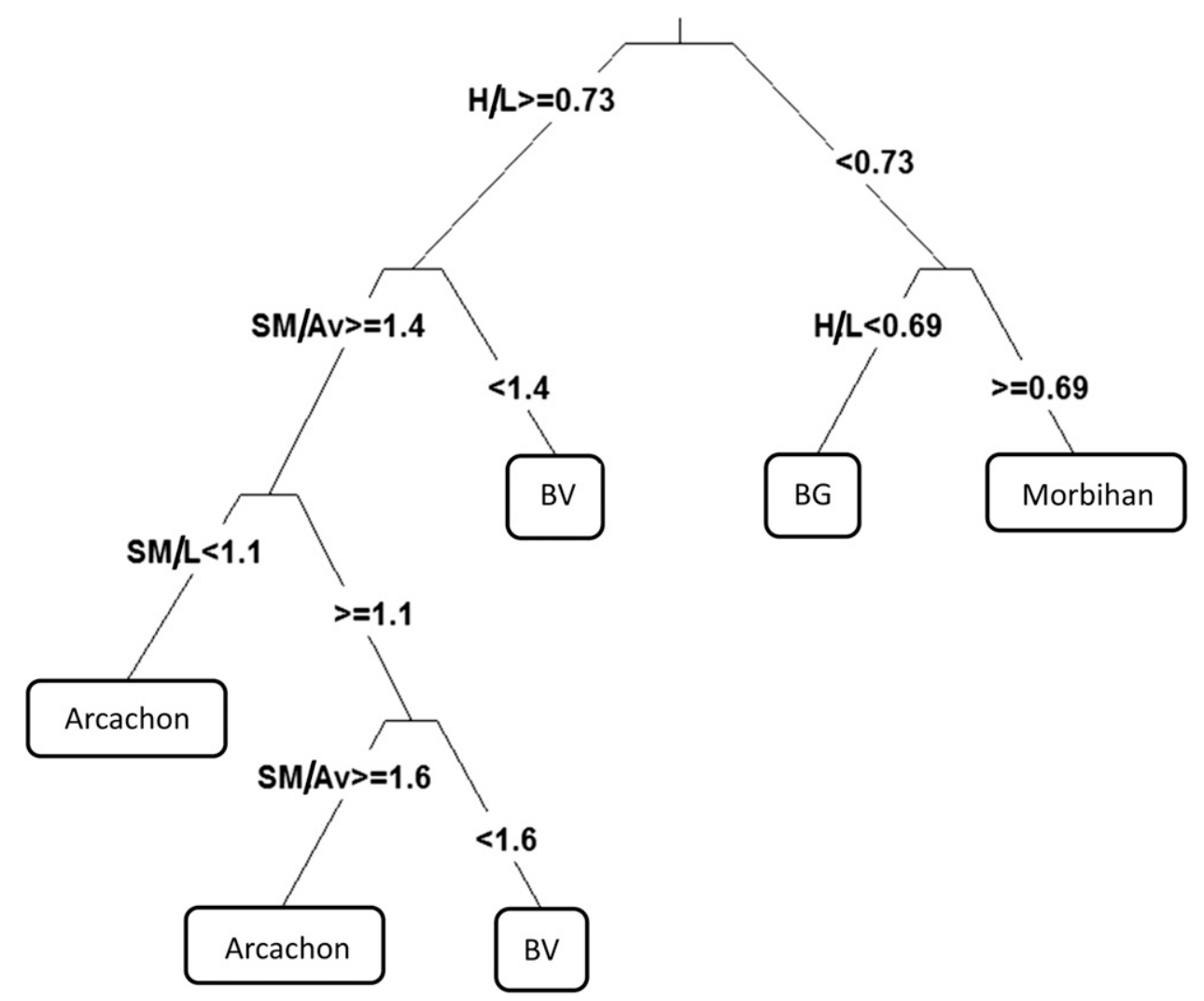

Figure 4. Plot of the selected classification tree obtained after pruning. BG, Banc du Guer; Morbihan, Morbihan Gulf; BV, Bellevue; Arcachon, Arcachon Bay.

(1988). Nevertheless, Costa et al. (2008) established that shell morphology was prevalently subject to local environmental conditions.

Given the results from studies using classic morphometric ratios, a complementary approach using the contour detection technique could be helpful in detecting shell morphological differences within and between sites. This approach was first used on 4 clam valves considered representative of each of the 4 sampling sites. In addition to providing illustrations of classic morphometric ratios, this technique also seemed to reveal different forms of anterior-dorsal shell valve margins. On the basis of these preliminary results, it would be interesting to pursue research in this area because the prosogyrous shape is known to reflect an adaptation to sediment characteristics in other bivalve species (Trueman et al. 1966, Stanley 1975, Eagar 1978). Rufino et al. (2006) used combined morphometric approaches (i.e., linear contour analysis and landmarks anal-

TABLE 5.

Confusion matrix related to the selected classification tree (expressed in \%).

\begin{tabular}{lcccc}
\hline \hline Real/Predicted & Arcachon Bay & Banc du Guer & Bellevue & $\begin{array}{c}\text { Morbihan } \\
\text { Gulf }\end{array}$ \\
\hline Arcachon Bay & 15 & 0 & 11 & 9 \\
Banc du Guer & 0 & 7 & 0 & 6 \\
Bellevue & 3 & 0 & 27 & 4 \\
Morbihan Gulf & 1 & 0 & 4 & 13 \\
\hline
\end{tabular}

ysis) to differentiate specimens of Chamelea gallina from its congener, Chamelea striatula.

\section{Learning from Supervised Classification Method and Considerations Regarding Management Strategies}

Implementation of data mining allowed us to avoid violation of assumptions required by traditional classification methods. Application of classification tree analysis to ecological data is a more recent method than linear discriminant analysis and quadratic discriminant analysis, which have been used widely in ecological studies for some time (Mercier et al. 2011). In this study, the classification tree permitted selection of three $\left(\frac{H}{L}, \frac{S M}{A v}\right.$, and $\left.\frac{S M}{L}\right)$, of the 8 available morphometric variables to distinguish shell shape differences among the 4 sites. This highlighted combination of just a few ratios contradicts the conventional wisdom that better accuracy is obtained by increasing the explicative variables number (Arslan \& Secor 2008). The resubstitution rate achieved was $38 \%$. Using the criterion established by Mercier et al. (2011) for otolith classifications, this resubstitution rate was considered to be intermediate. This result emphasized the complexity of the shape considerations and supports the combination of various morphometric approaches when examining morphometric difference between populations, as discussed earlier.

The interpretation level was more detailed for the sites with the highest sample numbers (i.e., Arcachon Bay and Bellevue), whereas the interpretation level was reduced for the sites with 
TABLE 6.

Linear multilevel models showing the effect of environmental parameters (related to temperature and chlorophyll $a$ ) on discriminatory morphometric ratios identified for Manila clam populations using classification techniques.

\begin{tabular}{|c|c|c|c|c|c|}
\hline \multirow[b]{2}{*}{$\begin{array}{l}\text { Morphometric } \\
\text { ratios }\end{array}$} & \multicolumn{2}{|c|}{ Step 1: null model } & \multicolumn{3}{|c|}{ Step 2: final model } \\
\hline & $\begin{array}{c}\text { Intraclass } \\
\text { correlation } \\
\text { coefficient }(\%)\end{array}$ & $\begin{array}{c}\text { Significance between null } \\
\text { model containing a random } \\
\text { spatial effect and one without }\end{array}$ & $\begin{array}{c}\text { Significant } \\
\text { environmental } \\
\text { variables }\end{array}$ & $\begin{array}{l}\text { Between-group intercept } \\
\text { variance explained by } \\
\text { predictors }(\%)\end{array}$ & $\begin{array}{l}\text { Significance between } \\
\text { null and final model }\end{array}$ \\
\hline$\frac{H}{L}$ & 61 & $P<0.0001$ t & $\begin{array}{l}\text { Median chlorophyll } a \\
\text { Chlorophyll } a \text { SD }\end{array}$ & 71 & $P=0.03325^{*}$ \\
\hline$\frac{\mathrm{SM}}{A v}$ & 27 & $P<0.0001$ & $\begin{array}{c}\text { T12_20 } \\
\text { Median chlorophyll } a \\
\text { Chlorophyll } a \text { SD }\end{array}$ & 88 & $P=0.01651^{*}$ \\
\hline$\frac{S M}{L}$ & 27 & $P<0.0001+$ & Median chlorophyll $a$ & 85 & $P=0.005284 \dagger$ \\
\hline
\end{tabular}

T12_20, percentage of temperature values between $12^{\circ} \mathrm{C}$ and $20^{\circ} \mathrm{C} . * P<0.05 . \dagger P<0.01 . \ddagger P<0.001$.

lower sample numbers (i.e., Morbihan and Banc du Guer). This may explain in part why only $55 \%$ of the clams from Banc du Guer were classified correctly. In Arcachon, which also displayed a high percentage of incorrectly classified individuals $(41 \%)$, this result may be connected with the spatial morphometric variability described recently by Caill-Milly et al. (2012). The Manila clam is characterized by its sedentary life history and aggregated distributions (Kalyagina 1994). In these conditions, the large spatial extent of the species within the bay (around $46 \mathrm{~km}^{2}$ [Sanchez et al. 2010]) associated with the high morphometric variability should promote spatial regulation within the bay. The importance of accounting for the spatial dimension in management strategies was emphasized by Defeo (2003) for sandy beach stocks. A review of successful case studies implying spatial dynamics was also undertaken by Caddy and Defeo (2003). Since 2000, in practice, such local legislation came to strengthen the European legislation in Arcachon Bay. It concerns protected surface areas, with localizations changing over time. These protected areas are part of a package of measures designed on a regional scale and implemented in a comanagement context. Provided that future research within the bay reveals significant relationships between morphometric and environmental conditions (e.g., between specific morphometric patterns reflecting good growth conditions and specific parameters describing living conditions), integration of morphometric considerations based on contour detection techniques might reinforce criteria regarding area delimitation.

\section{Normal Q-Q Plot}
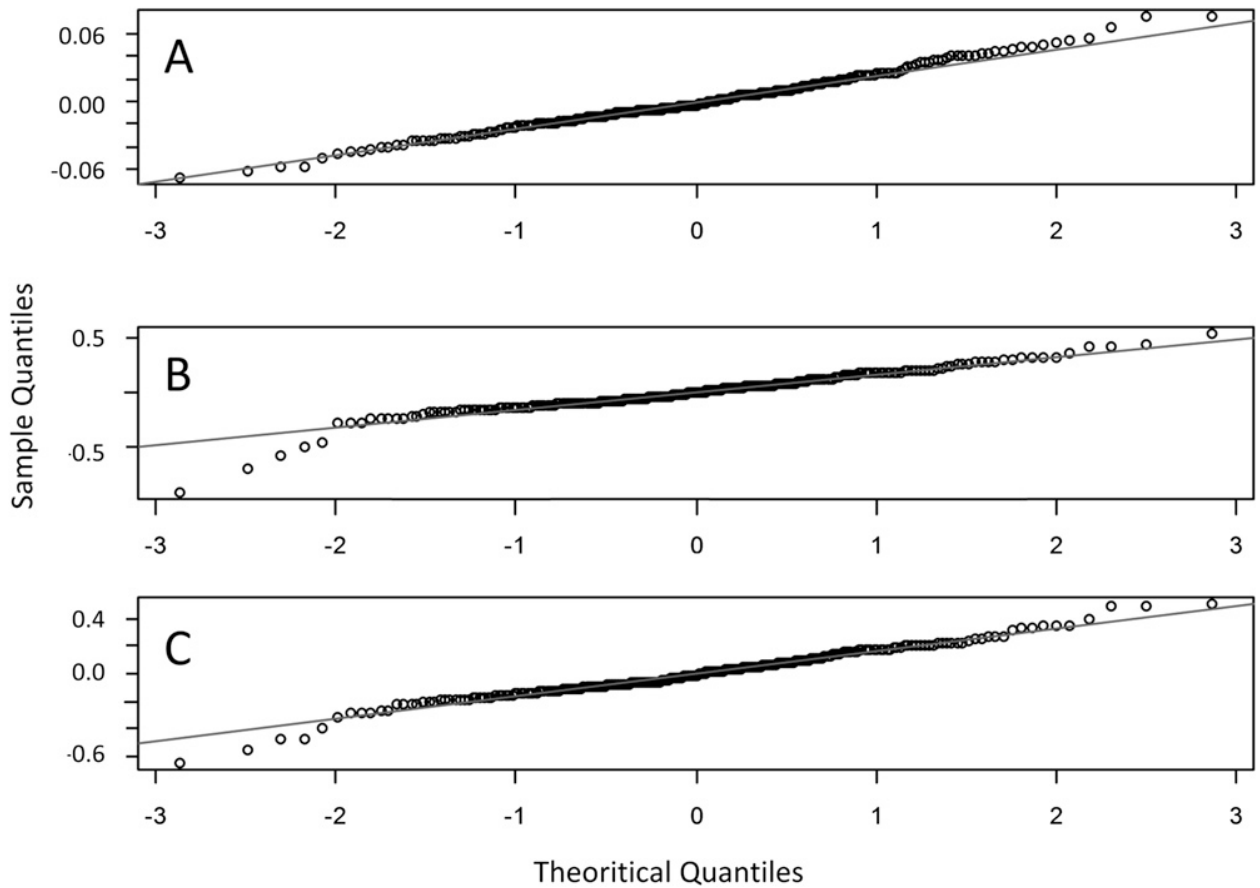

Figure 5. Normal Q-Q plots of the 3 multilevel linear models built for $\frac{H}{L}(\mathbf{A}), \frac{S M}{A v}(\mathbf{B})$, and $\frac{S M}{L}(\mathbf{C})$. 
An Unexpected Relationship Identified Between Morphometric Characteristics and Trophic Conditions

Implementation of LMMs on $\frac{H}{L}, \frac{S M}{A v}$, and $\frac{S M}{L}$ ratios revealed significant relationships with chlorophyll $a$ concentrations and, in 1 case, with seawater temperature between $12^{\circ} \mathrm{C}$ and $20^{\circ} \mathrm{C}$. As an indicator of valve density, $\frac{S M}{A v}$ was linked negatively with the optimum temperature range known to affect Manila clam growth (Maître-Allain 1982). These results are consistent with shell hypostracum growth. This inner layer of the valves has been demonstrated to be influenced positively by the maximum seawater temperature, and influenced negatively by pressure (Olson et al. 2012). This would suggest that the longer the temperature remains within the optimum range for growth, the greater the extent to which the formation of this inner shell layer is reduced, resulting in a decreased shell mass.

We identified a common relationship between trophic conditions measured as chlorophyll $a$ concentration and the 3 considered shell morphometric ratios. Round shape and heavy valves with regard to ventral area and length correlated positively with high median chlorophyll $a$ concentrations, but the 2 first ratios, $\frac{H}{L}$ and $\frac{S M}{A v}$, correlated negatively with increased variation in chlorophyll $a$ concentrations.

This result is surprising because good trophic conditions are expected to stimulate better growth characterized by slender shape and lightweight valves (Alumno-Bruscia et al. [2001] on Mytilus edulis; Watanabe and Katayama [2010] on Venerupis philippinarum).

To explain this apparent discrepancy with these previous studies, we identified 4 hypotheses. The first hypothesis is that chlorophyll $a$ is present in elevated quantities that lead to the opposite effect of the one expected. In the lagoon of Thau (France), Maître-Allain (1982) highlighted the existence of a threshold value regarding food supply beyond which the link between increase of growth rate and the quantity of chlorophyll $a$ no longer occurred. Gill filtration was thought to be disrupted by a clogging phenomenon. Based on the measured chlorophyll $a$ concentrations recorded in this study, this may have been the case.

The second hypothesis is that chlorophyll $a$ concentration is insufficient to account for trophic conditions usable by Manila clams and may mask other important food resources affecting shell growth. Such an assumption has already been challenged by Flye-Sainte-Marie (2008). As a bottom suspension-feeding bivalve, the Manila clam ingests not only phytoplankton (Kasai et al. 2004, Kanaya et al. 2005, Yokoyama et al. 2005, Spillman et al. 2008), but also filters the sediment-water interface to ingest bacteria (Kharlamenko et al. 2001), diatoms, detrital particulate organic matter, small rotifers (Sorokin \& Giovanardi 1995), dinoflagellates ( $\mathrm{Li}$ et al. 2001), and microphytobenthos (Kang et al. 2007).

Hypothesis 3 is that, because of trophic competition, the true quantity of food available for Manila clams is limited. For Arcachon, this issue was supported by the presence of other filter-feeding populations such as Crepidula fornicata, wild Crassostrea gigas (Dang 2009), and Mytilus edulis. Observations of numerous Ascidiacea have also been reported by De Montaudouin (pers. comm., July 2012). For the other sites, we have not identified such interspecific competition.
Four, and last, this apparent discrepancy with previous studies is the result of an effect of factors not taken into account in our study. We refer, in particular, to crowding, immersion time, and/or sediment effects. Competition for space is unlikely to occur because natural densities are so far at a much lower level than the densities considered to impact shell growth (Cigarría \& Fernandez 1998). Unfortunately, we do not currently have any data available on the other 2 listed factors. Their likely effects must not be neglected, particularly because sediment characteristics have proved to impact other Veneridae species considerably (Trueman et al. 1966, Stanley 1975, Eagar 1978). Thus, it seems relevant to undertake further research in this area.

Several authors have established that morphometric characteristics could reveal more or less favorable environmental conditions (Hamai 1935, Ohba 1959, Eagar et al. 1984) with, in particular for the Manila clam, demonstrations that morphological characteristics can be used as a proxy for nutritional conditions (Watanabe \& Katayama 2010). In these conditions, we tend to believe that the observed differences in shell shape responded to a combination of these 4 hypotheses to varying degrees, depending on site. These results highlight the complexity of the factors involved in Manila clam shell morphometry. Superimpositions of several factors and the difficulties in analyzing their impacts separately were reported by Orensanz et al. (1991).

In the current study, clams from southern sites exhibited overall greater elongation indices and ratios involving weight values than those from northern sites. Watanabe and Katayama (2010) demonstrated that high elongation indexes were associated with low condition factors, and they highlighted correlations between fast growth, thickness of the shell, and valve flatness. Referring to the results of Watanabe and Katayama (2010), and taking into account that the current study did not address valve thickness, the indicators of valve density used in this study suggest that clams from the southern sites had slower shell growth rates than individuals from the northern sites.

Dang et al. (2010) have described a reduced condition index and inferior shell growth (from $32 \mathrm{~mm}$ ) for Manila clams in Arcachon Bay compared with other sites. The hypothesis that less favorable conditions occur at this site makes it possible to use the indicators of valve density used in this study as proxies for condition and growth status. For the Bellevue Manila clam population, lack of similar data does not allow unqualified acceptance of this assumption at this time.

\section{CONCLUSIONS}

This study suggests, for the first time, morphometriclatitude trends for a Veneridae species. Based on intersite considerations, our results supported the relationship between bivalve size and latitude proposed by Berke et al. (2013) that focused on Bergmann's rule.

Conventional morphometric ratios integrating weight density indicators exhibit correlations with environmental parameters, particularly in relation to chlorophyll $a$ concentrations and, to a lesser extent, seawater temperature. Combined with the first implementation of an outline description, the highlighted patterns raise the question of the combined effect of environmental conditions on bivalve shell growth and morphology, and 
encourage further exploration of these possible relationships, notably by taking into account sediment characteristics.

The contribution of local adaptation to interpopulation morphological differentiation is a relatively poorly studied phenomenon (Costa et al. 2008). Elucidation of these effects should facilitate comprehension of the ecological traits of Manila clams on intersite- and intrasite-specific scales. It is all the more relevant that differences in life history traits can address topical ecological applications including fisheries conservation and management (Blanck \& Lamouroux 2007). Typically for the Manila clam, they should promote adequate spatial management strategies. On an intrasite-specific scale, this knowledge may help define appropriate protected areas if relationships between local morphological variations and environmental conditions are confirmed. On an intersite-specific scale, observations of morphological variation concomitant with low condition index and inferior shell growth above a certain size for some sites raises the following question: Is the unilateral application on the Euro- pean scale of a minimum harvest size based on length adequate regarding possible variation in shape?

\section{ACKNOWLEDGMENTS}

We are grateful to Gérard Véron and Ludovic Bouché for providing shell samples from Banc du Guer and Morbihan Gulf. We also thank Alain Briand, Raphael Le Guillou, and Michel Métais for their help in collecting Bellevue samples. We thank Marie-Noëlle de Casamajor and Muriel Lissardy, respectively, providing environmental data from Quadrige ${ }^{2}$ and localization maps. We thank Simplice Dossou-Gbété for his advice on statistical classifications procedures, and Chrystèle Mazières for English editing. We also thank the anonymous reviewers and Dr. Sandra E. Shumway for their constructive comments on the manuscript, including their advice on English grammar and style.

\section{LITERATURE CITED}

Akester, R. J. \& A. L. Martel. 2000. Shell shape, dysodont tooth morphology, and hinge-ligament thickness in the bay mussel Mytilus trossulus correlate with wave exposure. Can. J. Zool. 78:240-253.

Alumno-Bruscia, M., E. Bourget \& M. Fréchette. 2001. Shell allometry and length-mass-density relationship for Mytilus edulis in an experimental food-regulated situation. Mar. Ecol. Prog. Ser. 219:177-188.

Anonymous. 1975. Le Leguer, Fichier technique des estuaires bretons. Bureau d'étude de la SEPNB. Paris: CNEXO. 46 pp.

Anonymous. 2006. Schéma de mise en valeur de la Mer du Golfe du Morbihan. Vannes, France: SMVM 53 pp.

Anonymous. 2012a. Bretagne. Milieu. Hydrologie. http://envlit.ifremer.fr

Anonymous. 2012b. Poitou-Charentes. Milieu. Hydrologie. http://envlit. ifremer.fr

Arslan, Z. \& D. Secor. 2008. High resolution micromill sampling for analysis of fish otoliths by ICP-MS: effects of sampling and specimen preparation on trace element fingerprints. Mar. Environ. Res. 66:364-371.

Augris, C. \& L. Simplet. 2011. Atlas géologique de la baie de Lannion (Côtes-d'Armor - Finistère). Versailles, France: Ed. Quae. 112 pp.

Azandegde, A. 2010. Etude de la structure des communautés bactériennes du sédiment et de l'écologie de Vibrio aestuarianus pathogène de l'huître creuse Crassostrea gigas dans deux sites ostréicoles. $\mathrm{PhD}$ diss., University of Brest. 256 pp.

Bates, D., M. Maechler, B. Bolker \& S. Walker. 2013. lme4: linear mixed-effects models using Eigen and S4. R package version 1.0-5. Available at: http://CRAN.R-project.org/package=lme4

Beiras, R., A. P. Camacho \& M. Albentosa. 1994. Influence of temperature on the physiology of growth in Ruditapes decussatus (L.) larvae. J. Shellfish Res. 13:77-83.

Belin, C., D. Claisse, A. Daniel, E. Fleury, P. Le Mao, I. Amouroux, L. Miossec, A. Boisseaux, A. Lamoureux \& D. Soudant. 2013. Qualité du milieu marin littoral: synthèse nationale de la surveillance 2012 , edition 2013. Ifremer. 80 pp. Available at: http://envlit.ifremer.fr.

Ben Ouada, H., M. N. Medhioub, A. Medhioub, H. Jammoussi \& M. Beji. 1998. Variabilité morphométrique de la palourde Ruditapes decussatus (Linné, 1758) le long des côtes tunisiennes. Haliotis 27: 43-55.

Berke, S. K., D. Jablonski, A. Z. Krug, K. Roy, A. Tomašových \& J. W. Valentine. 2013. Beyond Bergmann's rule: size-latitude relationships in marine Bivalvia worldwide. Glob. Ecol. Biogeogr. 22:173-183.

Bernard, N. \& S. Chauvaud. 2002. Cartographie des habitats d'intérêt Européen du Golfe du Morbihan et de la Rivière Penef. Rapport télédétection et biologie marine (TBM). Rennes, France: DIREN Bretagne. 195 pp.

Beukema, J. J. \& B. W. Meehan. 1985. Latitudinal variation in linear growth and other shell characteristics of Macoma balthica. Mar. Biol. 90:27-33.

Blanck, A. \& N. Lamouroux. 2007. Large-scale intraspecific variation in life-history traits of European freshwater fish. J. Biogeogr. 34:862-875.

Bliese, P. 2012. Multilevel modeling in R (2.4): a brief introduction to R, the multilevel package and the nlme package. Available at: www.cran.r-project.org/doc/contrib/Bliese Multilevel.pdf.

Bourne, N. \& B. Adkins. 1985. Savary Island clam study. Report Fish. Aquat. Sci. 1848:69-95.

Brown, R. A., R. Seed \& R. J. O'Connor. 1976. A comparison of relative growth in Cerastoderma (= Cardium) edule, Modiolus modiolus, and Mytilus edulis (Mollusca: Bivalvia). J. Zool. Soc. London 179:297-315.

Caddy, J. F. \& O. Defeo. 2003. Enhancing or restoring the productivity of natural populations of shellfish and other marine invertebrate resources. FAO Fisheries Technical Paper. No. 448. Rome: FAO. 159 pp.

Cadrin, S. X. 2000. Advances in morphometric identification of fishery stocks. Rev. Fish Biol. Fish. 10:91-112.

Cadrin, S. X. \& K. D. Friedland. 2005. Morphometric outlines. In: S. X. Cadrin, K. D. Friedland \& J. R. Waldmann, editors. Stock identification methods: applications in fishery science. London: Elsevier Academic Press. pp. 173-183.

Caill-Milly, N., N. Bru, K. Mahé, C. Borie \& F. D’Amico. 2012. Shell shape analysis and spatial allometry patterns of Manila clam (Ruditapes philippinarum) in a mesotidal coastal lagoon. J. Mar. Biol. 2012. DOI: $10.1155 / 2012 / 281206$.

Canny, J. 1986. A computational approach to edge detection, pattern analysis and machine intelligence. IEEE Trans. 8:679-698.

Cigarría, J. \& J. Fernandez. 1998. Manila clam (Ruditapes philippinarum) culture in oyster bags: influence of density on survival, growth and biometric relationships. J. Mar. Biol. Assoc. UK 78:551-560.

Claxton, W. T., A. B. Wilson, G. L. Mackie \& E. G. Boulding. 1998. A genetic and morphological comparison of shallow- and deepwater populations of the introduced dreissenid bivalve Dreissena bugensis. Can. J. Zool. 76:1269-1276.

Costa, C., J. Aguzzi, P. Menesatti, F. Antonucci, V. Rimatori \& M. Mattoccia. 2008. Shape analysis of different populations of clams in relation to their geographical structure. J. Zool. (Lond.) 276:71-80.

Dame, R. F. 1972. Comparison of various allometric relationships in intertidal and subtidal American oysters. Fish Bull. 70:1121-1126. 
Dang, C. 2009. Dynamique des populations de palourdes japonaises (Ruditapes philippinarum) dans le bassin d'Arcachon: conséquences sur la gestion des populations exploitées. PhD diss., University of Bordeaux I. 356 pp.

Dang, C., X. de Montaudouin, M. Gam, N. Bru, C. Paroissin \& N. Caill-Milly. 2010. The Manila clam population in Arcachon Bay (SW France): can it be kept sustainable? J. Sea Res. 63:108-118.

Defeo, O. 2003. Marine invertebrate fisheries in sandy beaches: an overview. J. Coast. Res. S. I. 35:56-65.

Eagar, R. M. C. 1978. Shape and function of the shell: a comparison of some living and fossil bivalve mollusks. Biol. Rev. Camb. Philos. 53:169-210.

Eagar, R. M. C., N. M. Stone \& P. A. Dickson. 1984. Correlations between shape, weight and thickness of shell in four populations of Venerupis romboides (Pennant). J. Molluscan Stud. 50:19-38.

Fan, D., A. Zhang, Z. Yang \& X. Sun. 2007. Observations on shell growth and morphology of the bivalve Ruditapes philippinarum. Chin. J. Oceanol. Limnol. 25:322-329.

Fiori, S. \& O. Defeo. 2006. Biogeographic patterns in life-history traits of the yellow clam, Mesodesma mactroides, in sandy beaches of South America. J. Coast. Res. 22:872-880.

Flye-Sainte-Marie, J. 2008. Ecophysiology of brown ring disease in the Manila clam Ruditapes philippinarum: experimental and modelling approaches. PhD diss., Vrije Universiteit. 182 pp.

Franz, D. R. 1993. Allometry of shell and body weight in relation to shore level in the intertidal bivalve Geukensia demissa (Bivalvia: Mytilidae). J. Exp. Mar. Biol. Ecol. 174:193-207.

Fuiman, L. A., J. D. Gage \& P. A. Lamont. 1999. Shell morphometry of the deep sea protobranch bivalve Ledella pustulosa in the Rockall Trough, north-east Atlantic. J. Mar. Biol. Assoc. UK 79:661-671.

Gérard, G. 1978. Recherches sur la variabilité de diverses populations de Ruditapes decussatus et Ruditapes philippinarum (Veneridae, Bivalvia). PhD diss., Université de Bretagne Occidentale. 149 pp.

Geri, G., G. Parisi, P. Lupi, M. Mecatti, M. Dell'Agnello, M. Gualtieri \& R. Bozzi. 1996. Caratteristiche corporee in due specie di vongole [Tapes decussatus L. e. Tapes semidecussatus (Reeve] di taglia commercial. Zootec. Nutr. Anim. 22:103-118. (in Italian, with English abstract).

Hamai, I. 1935. A study of one case in which environmental conditions produce different types in Meretrix meretrix (L.). Sci. Rep. Tôhoku Univ. (Biol.) 10:485-498.

Hinch, S. G. \& R. C. Bailey. 1988. Within- and among-lake variation in shell morphology of the freshwater clam Elliptio complanata (Bivalvia: Unionidae) from southcentral Ontario lakes. Hydrobiologia 157:27-32.

Husson, F., J. Josse, S. Le \& J. Mazet. 2013. FactoMineR: multivariate exploratory data analysis and data mining with $\mathrm{R}$. R package version 1.25. Available at: http://CRAN.R-project.org/package $=$ FactoMineR.

Jarne, P., P. Berrebi \& O. Guélorget. 1988. Variabilité génétique et morphométrique de cinq populations de la palourde Ruditapes decussatus. Oceanol. Acta 11:401-407.

Kakino, J. 1996. Relationship between growth of Japanese little neck clam Ruditapes philippinarum and current velocity on Banzu tidal flat, Tokyo Bay. Bull. Chiba Pref. Fish. Exp. Stn. (in Japanese, with English abstract).

Kalyagina, E. E. 1994. Distribution and population structure of commercial bivalves Ruditapes philippinarum and Mya arenaria in Bousse Lagoon (Southern Sakhalin). Russ. J. Mar. Biol. 20(3):164 168.

Kanaya, G., E. Nobata, T. Toya \& E. Kikuchi. 2005. Effects of different feeding habits of three bivalve species on sediment characteristics and benthic diatom abundance. Mar. Ecol. Prog. Ser. 299:67-78.

Kang, C. K., Y. S. Kang, E. J. Choy, D. S. Kim, B. T. Shim \& P. Y. Lee. 2007. Condition, reproductive activity, and biochemical composition of the Manila clam, Tapes philippinarum in natural and newly created sandy habitats of the southern coast of Korea. J. Shellfish Res. 26:401-412.

Kasai, A., H. Horie \& W. Sakamoto. 2004. Selection of food sources by Ruditapes philippinarum and Mactra veneriformis (Bivalva: Mollusca) determined from stable isotope analysis. Fish. Sci. 70:11-20.

Kass, M., A. Witkin \& D. Terzopoulos. 1988. Snakes: active contour models. Int. J. Comput. Vis. 1:321-331.

Kharlamenko, V. I., S. I. Kiyashko, A. B. Imbs \& D. I. Vyshkvartzev. 2001. Identification of food sources of invertebrates from the seagrass Zostera marina community using carbon and sulfur stable isotope ratio and fatty acid analyses. Mar. Ecol. Prog. Ser. 220:103-117.

Kwon, J. Y., J. W. Park, Y. H. Lee, Y. K. Hong \& Y. J. Chang. 1999. Morphological variation and genetic relationship among populations of shortnecked clam Ruditapes philippinarum collected from different habitats. J. Fish. Sci. Technol. 2:98-104.

Laing, I., S. D. Utting \& R. W. S. Kilada. 1987. Interactive effect of diet and temperature on the growth of juvenile clams. J. Exp. Mar. Biol. Ecol. 113:23-28.

Le Hir, P., S. Kervella, P. Walker \& I. Brenon. 2010. Erosions, dépots et transits sédimentaires associés dans le basin de Marenne-Oléron. Houille Blanche 5:65-71.

Le Treut, Y. 1986. La palourde: Anatomie, biologie, élevage, pêche, consommation, inspection sanitaire. PhD diss., Ecole Nationale Vétérinaire, University of Nantes. 162 pp.

Li, S. C., W. X. Wang \& D. Hsieh. 2001. Feeding and absorption of the toxic dinoflagellate Alexandrium tamarense by two marine bivalves from the South China Sea. Mar. Biol. 139:617-624.

Lucas, A. 1981. Adaptations écophysiologiques des bivalves aux conditions de culture. B. Soc. Ecophysiol. 6:27-35.

Luttikhuizen, P. C., J. Drent, W. Van Delden \& T. Piersma. 2003. Spatially structured genetic variation in a broadcast spawning bivalve: quantitative vs. molecular traits. J. Evol. Biol. 16:260-272.

Maître-Allain, T. 1982. Influence du milieu sur la croissance de deux palourdes, Ruditapes decussatus et Ruditapes philippinarum, dans l'étang de Thau (Hérault). Vie Mar. 4:11-20.

Mariani, S., F. Piccari \& E. De Matthaeis. 2002. Shell morphometry in Cerastoderma spp. (Bivalvia: Cardiidae) and its significance for adaptation to tidal and non-tidal coastal habitats. J. Mar. Biol. Assoc. UK 82:483-490.

Márqueza, F., J. Robledo, G. Escati Peñaloza \& S. Van der Molen. 2010. Use of different geometric morphometrics tools for the discrimination of phenotypic stocks of the striped clam Ameghinomya antiqua (Veneridae) in north Patagonia, Argentina. Fish. Res. 101:127-131.

Mercier, L., A. M. Darnaude, O. Bruguier, R. P. Vasconcelos, H. N. Cabral, M. J. Costa, M. Lara, D. L. Jones \& D. Mouillot. 2011. Selecting statistical models and variable combinations for optimal classification using otolith microchemistry. Ecol. Appl. 21:1352-1364.

Moraga, D. 1984. Polymorphisme enzymatique de populations naturelles et expérimentales de la palourde Européenne Ruditapes decussatus (L.) (Veneridae, Bivalvia). PhD diss., Université de Bretagne Occidentale. 114 pp.

Nagarajana, R., S. E. G. Lea \& J. D. Goss-Custard. 2006. Seasonal variations in mussel, Mytilus edulis L. shell thickness and strength and their ecological implications. J. Exp. Mar. Biol. Ecol. 339:241-250.

Nakamura, Y., M. Hagino, T. Hiwatari, A. Iijima, K. Kohata \& T. Furota. 2002. Growth of the Manila clam, Ruditapes philippinarum in Sanbanse, the shallow coastal area in Tokyo Bay. Fish. Sci. 68:1309-1316

Ohba, S. 1956. Effect of population density on mortality and growth in an experimental culture of bivalve, Venerupis semidecussata. Biol. J. Okayama Univ. 112:169-173.

Ohba, S. 1959. Ecological studies in the natural population of a clam, Tapes japonica, with special reference to seasonal variations in the size and structure of the population and to individual growth. Biol. J. Okayama Univ. 5:13-42. 
Olson, I. C., R. Kozdon, J. W. Valley \& P. U. P. A. Gilbert. 2012. Mollusk shell nacre ultrastructure correlates with environmental temperature and pressure. J. Am. Chem. Soc. 134:7351-7358.

Orensanz, J. M., A. M. Parma \& O. O. Iribarne. 1991. Population dynamics and management of natural stocks. In: S. E. Shumway, editor. Scallop: biology, ecology and aquaculture: developments in aquaculture and fisheries science, vol. 21. Amsterdam: Elsevier. pp. 625-713.

Pinheiro, J., D. Bates, S. DebRoy, D. Sarkar \& the R Development Core Team. 2014. nlme: linear and nonlinear mixed effects models. R package version 3.1-111. Available: http://CRAN.R-project.org/ package $=$ nlme

Plus, M., D. Maurer, J. Y. Stanisière \& F. Dumas. 2006. Caractérisation des composants hydrodynamiques d'une lagune mésotidale, le bassin d'Arcachon. Rapport Ifremer. RST/LER/AR/06.007. Arcachon, France: Ifremer. 58 pp.

R Core Team. 2013. R: a language and environment for statistical computing. Vienna: Austria. R Foundation for Statistical Computing. Available: http://www.R-project.org/.

Rosenberg, G. D. 1972. Patterned growth of the bivalve Chione undatella (Sowerby) relative to the environment. PhD diss., University of California. $220 \mathrm{pp}$.

Rufino, M. M., M. B. Gaspar, A. M. Pereira \& P. Vasconcelos. 2006. Use of shape to distinguish Chamelea gallina and Chamelea striatula (Bivalvia: Veneridae): linear and geometric morphometric methods. J. Morphol. 267:1433-1440.

Sanchez, F., N. Caill-Milly, M. Lissardy, M. N. de Casamajor \& G. Morandeau. 2010. Campagne d'évaluation du stock de palourdes du bassin d'Arcachon - Année 2010, Rapport Ifremer DCN/HGS/ LRHA10-003. 47 pp.

Seed, R. 1968. Factors influencing shell shape in the mussel, Mytilus edulis L. J. Mar. Biol. Assoc. UK 48:561-584.

Shibata, T., M. Toba, M. Sakai \& A. Kaneko. 1999. Availability of photo-pigment as an index of productivity in the culture ground of
Japanese little neck clam Ruditapes philippinarum. Bull. Chiba Pref. Fish. Exp. Stn. 55:67-72.

Sorokin, Y. \& O. Giovanardi. 1995. Trophic characteristics of the Manila clam (Tapes philippinarum Adams and Reeve). ICES J. Mar. Sci. 52:853-862.

Spillman, C. M., D. P. Hamilton, M. R. Hipsey \& J. Imberger. 2008. A spatially resolved model of seasonal variations in phytoplankton and clam (Tapes philippinarum) biomass in Barbamarco lagoon, Italy. Estuar. Coast. Shelf Sci. 79:187-203.

Stanley, S. M. 1975. Adaptative themes in the evolution of the Bivalvia (Mollusca). Annu. Rev. Earth Planet. Sci. 3:361-385.

Therneau, T., B. Atkinson \& B. Ripley. 2013. rpart: recursive partitioning. R package version 4.1-3. Available at: http://CRAN.R-project. org/package $=$ rpart.

Toba, M. 1987. Ruditapes philippinarum: growth of larvae and juveniles artificially fertilized. Bull. Chiba Pref. Fish. Exp. Stn. 45:41-48.

Tomaru, Y., Y. Kumatabara, Z. Kawabata \& S. Nakano. 2002. Effects of water temperature and chlorophyll abundance on shell growth of the Japanese pearl oyster, Pinctada fucata martensii, in suspended culture at different depths and sites. Aquacult. Res. 33:109-116.

Trueman, E. R., A. R. Brand \& P. Davis. 1966. The effect of substrate and shell shape on the burrowing of some common bivalves. Proc. Malacol. Soc. London 37:97-109.

Watanabe, S. \& S. Katayama. 2010. Relationships among shell shape, shell growth rate, and nutritional condition in the Manila clam (Ruditapes philippinarum) in Japan. J. Shellfish Res. 29:353-359.

Yokoyama, H., A. Tamaki, K. Koyama, Y. Ishihi, K. Shimoda \& K. Harada. 2005. Isotopic evidence for phytoplankton as a major food source for macrobenthos on an intertidal sandflat in Ariake Sound, Japan. Mar. Ecol. Prog. Ser. 304:101-116.

Yonge, C. M. \& J. I. Campbell. 1968. On the heteromyarian conditions in the Bivalvia with special reference to Dreissena polymorpha and certain Mytilacea. Trans. R. Soc. Edinb. 68:21-43.

\section{APPENDIX}

TABLE A1.

Mean ratios (SDs) for the 8 morphometric indices per site.

\begin{tabular}{llcll}
\hline \hline & Banc du Guer & Morbihan Gulf & Bellevue & Arcachon Bay \\
\hline$\frac{H}{L}$ & $0.69(0.02)$ & $0.72(0.02)$ & $0.76(0.03)$ & $0.75(0.03)$ \\
$\frac{W}{L}$ & $0.28(0.02)$ & $0.29(0.02)$ & $0.31(0.02)$ & $0.29(0.02)$ \\
$\frac{W}{H}$ & $0.41(0.03)$ & $0.40(0.03)$ & $0.41(0.03)$ & $0.39(0.02)$ \\
$\frac{S M}{L}$ & $0.84(0.12)$ & $0.85(0.13)$ & $1.06(0.17)$ & $0.99(0.21)$ \\
$\frac{S M}{H}$ & $1.22(0.17)$ & $1.18(0.17)$ & $1.40(0.20)$ & $1.32(0.25)$ \\
$\frac{S M}{W}$ & $2.96(0.31)$ & $2.98(0.38)$ & $3.43(0.40)$ & $3.43(0.60)$ \\
$\frac{S M}{A l}$ & $0.43(0.06)$ & $0.42(0.06)$ & $0.50(0.07)$ & $0.47(0.09)$ \\
$\frac{S M}{A v}$ & $1.20(0.12)$ & $1.20(0.14)$ & $1.37(0.15)$ & $1.42(0.23)$ \\
\hline
\end{tabular}



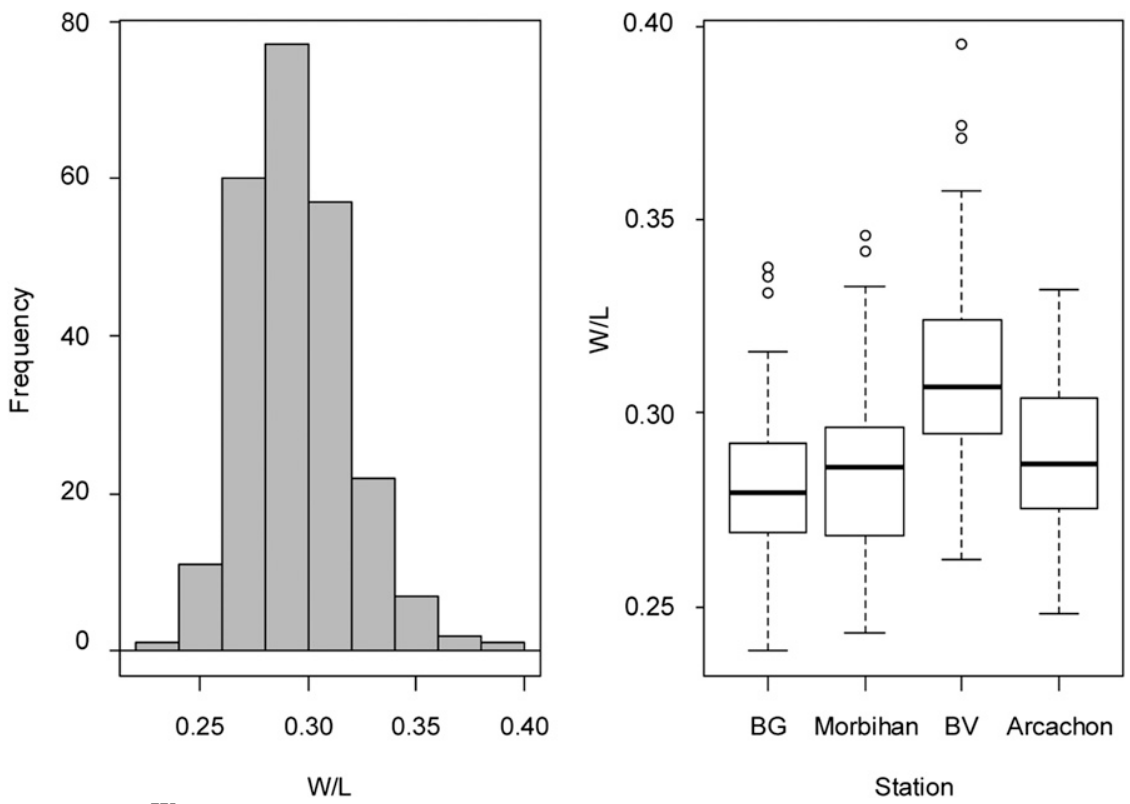

Figure A1. $\frac{W}{L}$ frequency distribution for the entire data set and box plot according to factor site.
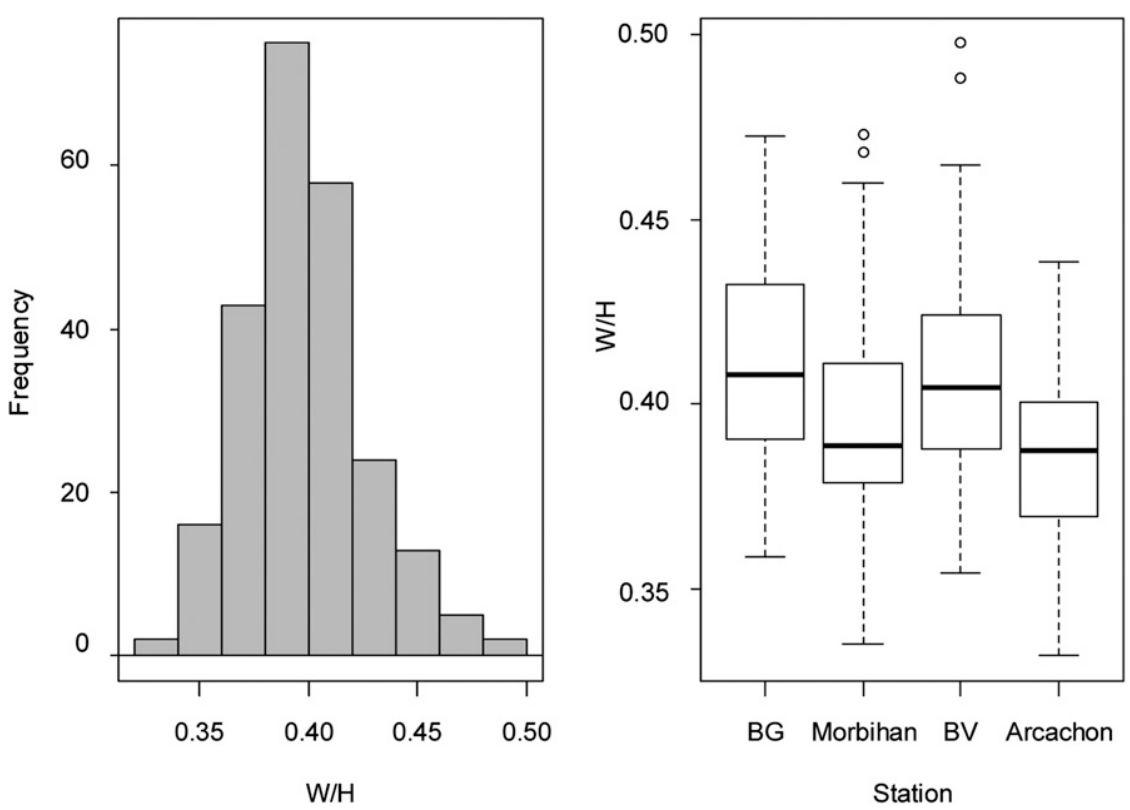

Figure A2. $\frac{W}{H}$ frequency distribution for the entire data set and box plot according to factor site. 

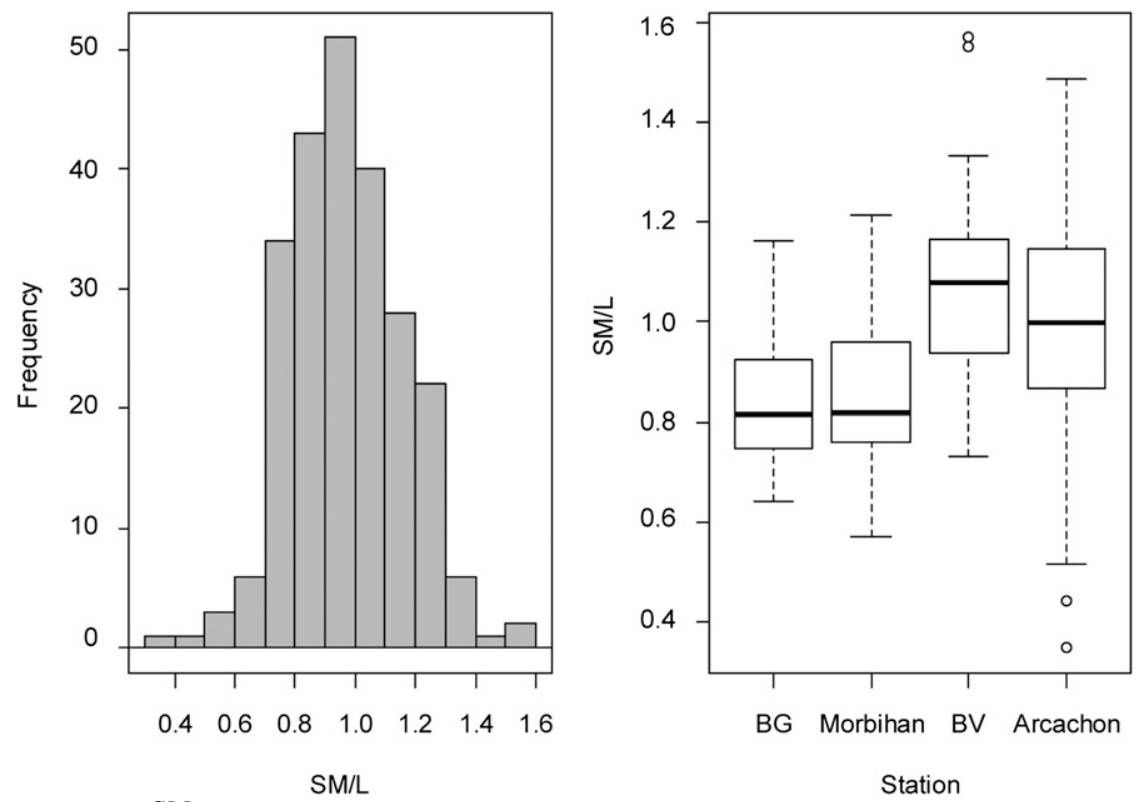

Figure A3. $\frac{S M}{L}$ frequency distribution for the entire data set and box plot according to factor site.
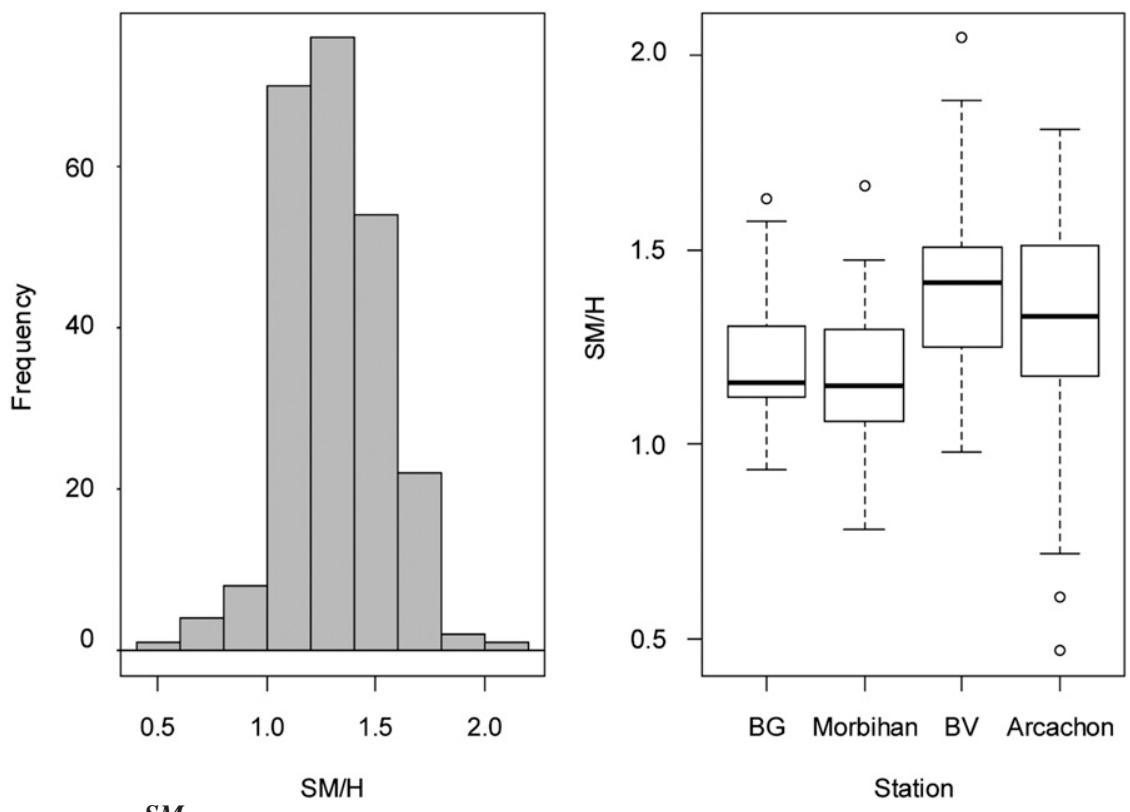

Figure A4. $\frac{S M}{H}$ frequency distribution for the entire data set and box plot according to factor site. 

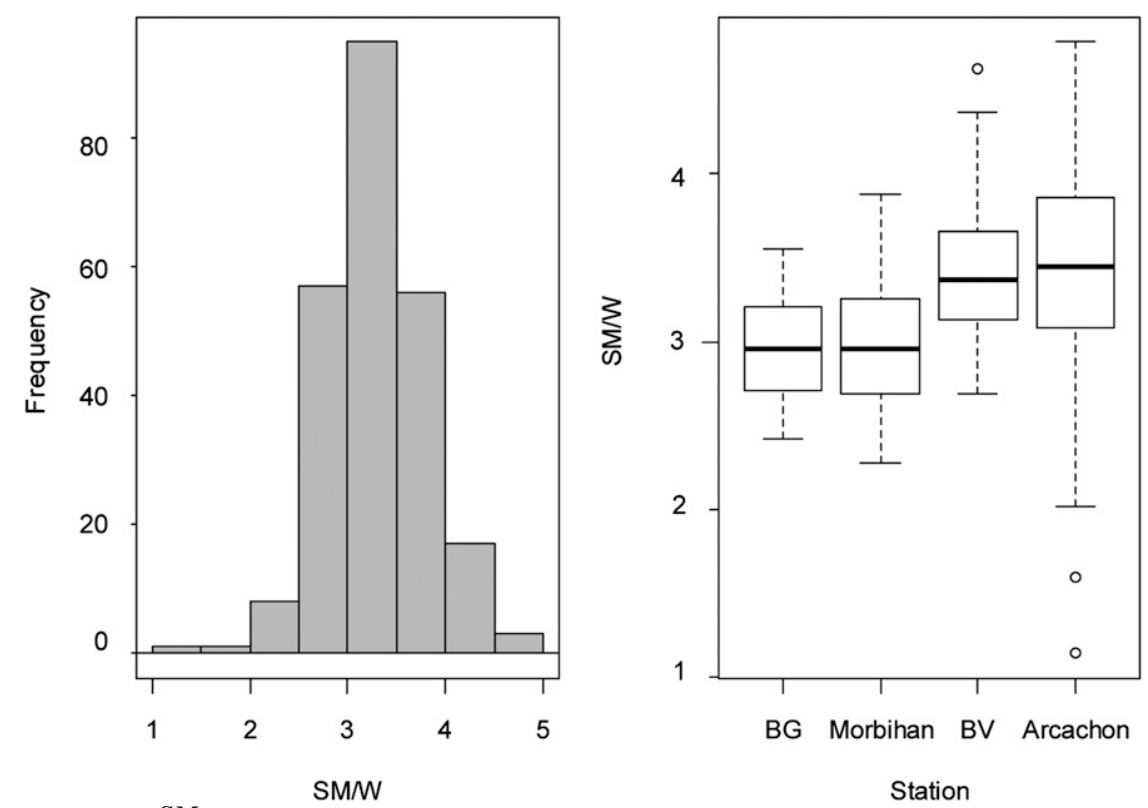

Figure A5. $\frac{S M}{W}$ frequency distribution for the entire data set and box plot according to factor site.
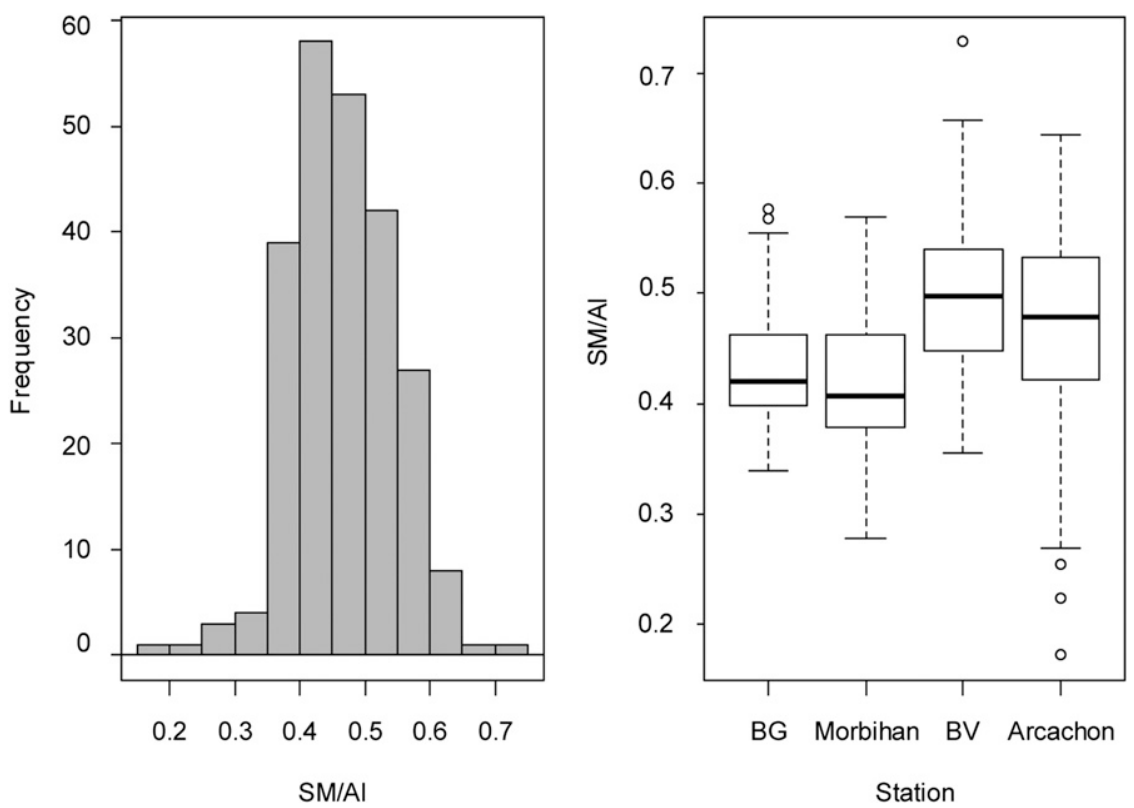

Figure A6. $\frac{S M}{A l}$ frequency distribution for the entire data set and box plot according to factor site. 

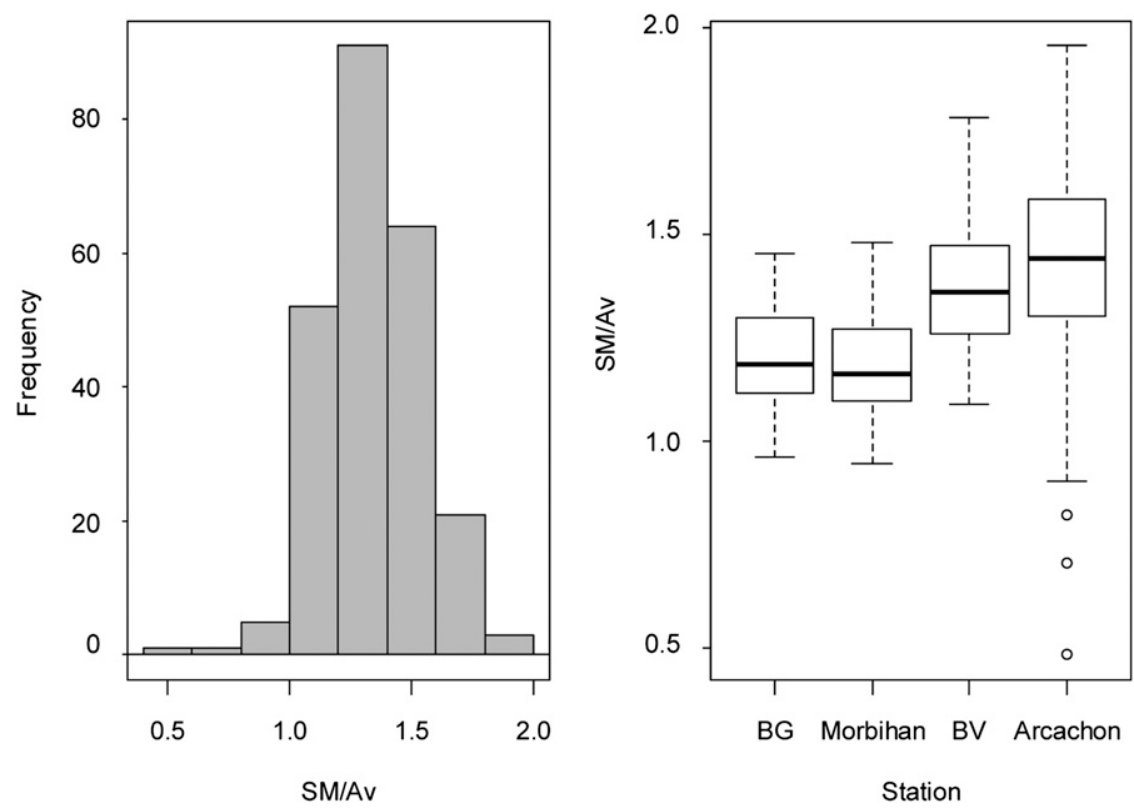

Figure A7. $\frac{S M}{A v}$ frequency distribution for the entire data set and box plot according to factor site. 